\title{
En kort innføring i folkerettslig traktatstolking
}

\author{
Amrei Müller
}

\section{Innledning ${ }^{1}$}

I denne artikkelen vil jeg gi en kort innføring i tolkning av folkerettslige traktater. Traktatstolkning er av stor betydning i folkeretten, som regulerer stadig flere områder og som samtidig har stadig større innflytelse på nasjonale rettssystemer. Traktatstolkning er relevant for mange aktører - ikke bare internasjonale, som for eksempel internasjonale dommere, men også nasjonale, som for eksempel dommere eller saksbehandlere i et departement. Dessuten kan mange - både stater og enkeltpersoner - bli direkte påvirket av traktatstolkning.

For å forstå den store betydningen traktatstolkning har i folkeretten kan vi spørre: Hvorfor trenger vi å tolke traktater? Først kan vi fremheve at i dag har traktater en sentral funksjon som rettskilde i folkeretten. I Wien-konvensjonen om traktatretten av 23. mai 1969 defineres en «treaty» som:

«[A]n international agreement concluded between States in written form and govererned by international law, whether embodied in a single instrument of in two or more related instruments and whatever its particular desigantion. $»^{2}$

Som enhver annen lovtekst, må også traktater tolkes. Slik tolkning er nødvendig for å utlede partenes gjensidige rettigheter og plikter etter traktaten. Det som imidlertid skiller folkerettslige traktater fra andre avtaler eller nasjonal lovgivning, er at de er et resultat av multilaterale eller bilaterale forhandlinger, først og fremst mellom suverene stater. Store meningsforskjeller mellom likeverdige stater under forhandlingene fører ofte til kompromisser, som deretter blir til vage eller tvetydige traktatsbestemmelser. Man kan ikke tillate at alle tolker en traktat slik de selv ønsker. Det ville ført til høy rettsusikkerhet både i folkeretten og i nasjonal rett. Det kan dessuten resultere i en uenhetlig folkerettsutvikling og i verste fall til mellomstatlige spenninger, som er nettopp det suverene stater som regel ønsker å unngå ved inngåelse av traktater. Derfor har man innenfor folkeretten utviklet bindende regler om traktatstolkning som må følges av alle folkerettssubjekter, fortrinnsvis stater og internasjonale organisasjoner, ved tolkning og anvendelse av traktater.

A kjenne til og anvende disse tolkningsreglene er, som sagt, nødvendig for dommere i internasjonale domstoler som skal løse tvister mellom stater. Vanligvis dreier tvistene seg om tolkning av enkelte traktatsbestemmelser. Traktater må imidlertid også ofte tolkes av nasjonale myndigheter, også de norske myndigheter. For eksempel må juridiske rådgivere i Utenriksdepartementet og i Justis- og beredskapsdepartementet kunne tolke traktater i tråd med folkerettslige regler om traktatstolkningfor å vite hvilke plikter og rettigheter Norge har overfor andre stater. Ettersom nasjonal lovgiving og folkeretten har blitt mer og mer sammenvevd de siste

\footnotetext{
${ }^{1}$ Artikkelen er basert på en forelesning til BA-studenter holdt ved Universitetet i Agder i September 2016. Jeg vil gjerne takke Jussens Venners redaktørene for nyttige kommentarer til tidligere versjoner av artikkelen, og Marit Fosse, Tori Loven Kirkebø og Ester Jørgensen Strømmen for hjelp med språkvask.

${ }^{2}$ Wien-konvensjonen om traktatretten (Vienna Convention on the Law of Treaties (VCLT)), trådt i kraft 27. januar 1980, 1155 UNTS 331, artikkel 2 første ledd.
} 
årene, ${ }^{3}$ må også nasjonale domstoler stadig oftere tolke traktater. Dette er bekreftet av norsk Høyesterett flere ganger. ${ }^{4}$ Her er menneskerettighetstraktater som beskytter enkeltpersoners rettigheter spesielt viktige. Til syvende og sist betyr dette at norske jurister og jusstudenter er nødt til å studere folkerettslige regler om traktatstolkning.

De hensyn som ligger til grunn for reglene om traktatstolkning skiller seg til dels fra de som norsk avtalerett bygger på. Ved traktatstolkning gjør en del spesielle hensyn seg gjeldende: statens suverenitet og det tilknyttede faktum at alle stater er selvstendige og likeverdige traktatsparter, stabilitet $\mathrm{i}$ internasjonale og mellomstatlige forhold, og behovet for å tilpasse folkererettssytemet $\mathrm{i}$ tråd med skiftende (globale) forhold. ${ }^{5}$ Hvilken vekt disse ulike hensyn tillegges i ulike deler av folkeretten varierer. Dette kommer jeg noe nærmere inn på i enkelte deler av artikkelen.

Før jeg går over til å behandle de folkerettslige reglene som styrer traktatstolkningen, vil jeg nevne en annen grunn til hvorfor traktatstolkning er av stor praktisk betydning. Tolkning av folkerettslige traktater kan på samme måte som tolkning av nasjonale lover i stor grad påvirke livet til enkeltmennesker. Et eksempel er Den europeiske menneskerettighetskonvensjonen ${ }^{6}$ (EMK) artikkel 1. Det står der:

«The High Contracting Parties shall secure to everyone within their jurisdiction the rights and freedoms defined in ... this Convention.» (Min utheving.)

Avhengig av hvordan vi tolker «jurisdiction» vil en person enten være, eller ikke være, beskyttet av menneskerettighetene. Man kan argumentere for at «jurisdiction» kun sikter til territoriell jurisdiksjon. ${ }^{8}$ I så fall er det bare personer som oppholder seg innenfor en stats grenser som er under statens «jurisdiction». Personer hvis menneskerettigheter blir krenket utenfor nasjonalt territorium - for eksempel ved bombing, okkupasjon eller hemmelige etterretningstjenesters aktiviteter utenlands - vil da ikke være beskyttet av menneskerettighetene. På den andre siden kan vi tolke ordet «jurisdiction» slik at det også omfatter tilfeller hvor en stat krenker menneskerettigheter til personer utenfor deres landegrenser. Med andre ord kan vi forstå «jurisdiction» på en slik måte at det også omfatter de tilfeller hvor myndighet blir utøvet ekstra-

\footnotetext{
${ }^{3}$ I norsk sammenheng har dette blitt analysert for eksempel av Finn Arnesen og Are Stenvik, Internasjonalisering og juridisk metode - Sarlig om EØS-rettens betydning i norsk rett, 2. utgave, Oslo 2015, Mads Andenæs, Andreas Motzfeldt Kravik og Eirik Bjørge, «Menneskerettsspørsmål for Høyesterett som EMD ikke har tatt stilling til», Lov og Rett, 2015 s. 323-343 og Halvard Haukeland Fredriksen, «Hvem avgjør tolkningen av EØS-avtalen?», Tidsskrift for Rettsvitenskap, 2010 s. 247-287.

${ }^{4}$ Se for eksempel Rt. 2000 s. 996 P (Bøhlerdommen), Rt. 2010 s. 1170, Rt. 2001 s. 1006, Rt. 2002 s. 557, Rt. 2008 s. 1409 og Rt. 2004 s. 1737. For mer informasjon se Jørgen Aall, Rettstat og mennekerettigheter, 3. utgave, Bergen 2011, Ola Wiklund, «The Reception Process in Sweden and Norway», i A Europe of Rights - The Impact of the ECHR on National Legal Systems, Oxford 2008, s. 198-207, Mads Andenæs og Andreas Motzfeldts Kravik, «Norske verdier og EMK» Lov og Rett, 2010 s. 579-599; og Amrei Müller, «Oslo - Strasbourg - back to Oslo and/or into Wider Europe? The ECtHR’s Engagement with the Decisions of Norwegian Courts for Strengthening the Convention System as a Cooperative System», Nordic Journal of Human Rights, 2015 s. 11-51.

${ }^{5}$ Se Morten Ruud og Geir Ulfstein, Innforing i folkerett, 4. utgave, Oslo 2011 s. 81.

${ }^{6}$ Den europeiske menneskerettighetskonvensjonen (Convention for the Protection of Human Rights and Fundamental Freedoms), 213 UNTS 222; 312 ETS 5, trådt i kraft 3. september 1953.

${ }^{7}$ Sitater fra traktater og internasjonale dommer er gitt på engelsk fordi det er et av de offisielle språkversjoner i de traktater og dommer som analyseres. Svært få avtaler og dommer har norsk som et offisielt språk. Flerspråklige traktater analyseres i detalj under punkt 6 nedenfor.

${ }^{8}$ For diskusjonen rundt dette spørsmålet i akademisk litteratur, se: Samantha Besson, «The Extraterritoriality of the European Convention on Human Rights: Why Human Rights Depend on Jurisdiction and What Jurisdiction Amounts to», Leiden Journal of International Law, 2012 s. 857-884 og Marko Milanovic, Extraterritorial Application of Human Rights Treaties, Oxford 2011.
} 
territorielt - $\mathrm{i}$ alle fall når staten har effektiv kontroll over enkeltpersoner eller befolkningen utenfor egne landegrenser. ${ }^{9}$ Avhengig av den tolkningen man velger er enkeltmennesket enten beskyttet av EMK eller ikke. Dette valget er også avgjørende for om individet har rett til å bringe en klage om påståtte brudd på EMK til Den europeiske menneskerettighetsdomstolen (EMD).

Det finnes mange andre eksempler på hvordan tolkningen av en traktat påvirker menneskers liv. Bare tenk på traktater som regulerer bruk av våpen; ${ }^{10}$ regler om internasjonal handel, som kan tolkes på en måte som enten fremmer eller ødelegger personers levebrød eller miljøet, ${ }^{11}$ eller klimatraktater hvor tolkningen vil kunne komme til å påvirke fremtiden vår. Dette innebærer at de som tolker traktater - nasjonale og internasjonale jurister - har et stort ansvar. De må gjøre det på en nøyaktig og gjennomtenkt måte, og vi må ha regler om traktatstolkning som begrenser handlingsrommet til rettsanvenderen. I den sammenheng vises det til et sitat fra Philip Allott, som tydelig fremhever dette ansvaret:

«[A] legal text has the exceptional characteristic that its interpretation may be applied, with the social authority of the law, to cause actual real-world consequences and to change the lives of actual people.

This imposes a special responsibility on [the creator and] the interpreter of a legal text.»12

Bortsett fra korte bidrag, ${ }^{13}$ er det ikke skrevet mye i norsk juridisk litteratur om de folkerettslige regler om traktatstolkningen, som begrenser de (i teorien) uendelige tolkningsmulighetene som vage traktatsbestemmelser åpner for. Artikkelens siktemål er å gi et lite bidrag til norsk folkerettslig litteratur, og en kort innføring i tolkning av folkerettslige traktater. I artikkelen drøftes de viktigste reglene om traktatstolkning som finnes i Wien-konvensjonen om traktatretten, særlig i artikkel 3133. Jeg vil først kort introdusere Wien-konvensjonen (punkt 2) og deretter analysere hovedregelen om tolkning i Wien-konvensjonen artikkel 31 (punkt 3). I punkt 4 undersøker jeg det temporale elementet og den dynamiske tolkningsstilen, mens jeg i punkt 5 behandler supplerende tolkningsmomenter som finnes i Wien-konvensjonen artikkel 32. Deretter ser jeg i punkt 6 på tolkning av traktater som er utarbeidet på flere språk. Artikkelen avsluttes i punkt 7 med noen korte refleksjoner.

\section{Wien-konvensjonen om traktatretten}

Wien-konvensjonen om traktatretten kodifiserte mange fokerettslige sedvaneregler for tolkning av traktater i 1969. Dette fremgår av rapporter fra FNs folkerettskommisjon (International Law

\footnotetext{
${ }_{9}^{9}$ Det er en slik tolkning EMD har lagt til grunn i for eksempel Hassan mot Storbritannia, søkenummer 29750/09, storkammerdom 16. september 2014 avsnitt 74-80; Medvedyev mot Frankrike, søkenummer 3394/03, storkammerdom 29. mars 2010 avsnitt 62-67; og Mozer mot Republikken Moldova og Russland, søkenummer 11138/10, storkammerdom 23. februar 2016 avsnitt 96-112.

${ }^{10}$ For eksempel Convention on Cluster Munitions, trådt i kraft 1. august 2010, 2688 UNTS 39.

${ }^{11}$ Se for eksempel analysen av Elisabeth Fisher, Risk Regulation and Administrative Constitutionalism, Oxford 2007 særlig kapittel 5 og 6 .

12 Philip Allott, «Interpretation - An Exact Art», i Interpretation in International Law, Oxford 2015 s. 373.

${ }^{13}$ Se Ruud og Ulfstein, Innforing i folkerett (2011), s. 88-95; Eirik Bjørge, «Dynamisk tolkning i den generelle folkeretten», Lov og Rett, 2012 s. 104-122, Jens Edvin Skoghøy, «Dynamisk tolking i internasjonale domstoler som fenomen, problem og effektivitetsgaranti» Lov og Rett, 2011 s. 511-530, Frode Elgesem, «Tolkning av EMK - Menneskerettsdomstolens metode», Lov og Rett, 2003 s. 203-230, Mads Andenæs og Eirik Bjørge, «Den europeiske menneskerettskonvensjonen og tropper i utlandet: tilbake til folkerettens alminnelige regler?», Retfard, 2012 s. 41-68, Sverre Lodgaard, «Sikkerhetsrådets resolusjon 1973 om beskyttelse av sivilbefolkningen i Libya», Lov og Rett, 2012 s. 359-362, og Kjetil Mujezinović Larsen, «Tolkning av sikkerhetsrådsresolusjoner - en kommentar til Sverre Lodgaard», Lov og Rett, $2012 \mathrm{~s}$. 363-369.
} 
Commision) som var tungt involvert i utarbeidelsen av Wien-konvensjonen. ${ }^{14}$ Dette betyr at Wienkonvensjonen i utgangspunktet anvendes ved tolkning av alle traktater, også de som ble vedtatt før 1980, da Wien-konvensjonen trådte i kraft. ${ }^{15}$ Den internasjonale domstolen (ICJ) har bekreftet i mange saker etter 1969 at de fleste bestemmelsene i Wien-konvensjonen anses som folkerettslig sedvanerett, ${ }^{16}$ særlig artikkel 31-33 om traktatstolkning. Eksempler er ICJs uttalelser i Arbitral Award-saken fra 1991 (Guinea-Bissau mot Senegal), ${ }^{17}$ Territorial Dispute-saken (Libya mot Chad) fra 1994, ${ }^{18}$ i Kasikili/Sedudu Island-saken (Botswana mot Namibia) fra $1999^{19}$ og i Oljeplattform-saken fra 2003 (Iran mot USA). ${ }^{20}$ Dessuten har Verdens handelsorganisasjons klageinstans (WTO appellate body) ${ }^{21}$ og EMD ${ }^{22}$ funnet at artikkel 31-33 gir uttrykk for folkerettslig sedvanerett.

Norge har ikke underskrevet eller ratifisert Wien-konvensjonen, men som andre ikke-parter til Wien-konvensjonen er Norge likevel bundet ${ }^{23}$ av de bestemmelsene som anses som folkerettslig sedvanerett, blant annet artikkel 31-33.

\section{Wien-konvensjonen artikkel 31: hovedregelen om tolkning}

\subsection{Innledning}

Hovedbestemmelsen for tolkning av traktater finner man i Wien-konvensjonen artikkel 31 første avsnitt:

«A treaty shall be interpreted in good faith in accordance with the ordinary meaning to be given to the terms of the treaty in their context and in the light of its object and purpose.» (Min utheving.)

Fra de fire fremhevede begrepene i bestemmelsen er det klart at det er fire elementer/momenter som må tas hensyn til i enhver tolkning: «ordinary meaning», «context», «object and purpose» samt «good faith». I dette punktet, punkt 3, vil jeg forklare disse elementene i mer detalj.

Før jeg går over til det, vil jeg komme med to innledende bemerkninger. Først vil jeg understreke det viktige poenget at artikkel 31, herunder andre og tredje avsnitt, som blir analysert senere, må leses og anvendes som en helhet. ${ }^{24}$ Dette til tross for at vi finner disse elementene som fire separate tolkningsmomenter. Rekkefølgen gir ikke uttrykk for et hierarki mellom tolkningsmomentene. Ved enhver fortolkning må man derfor ta hensyn til samtlige elementer $\mathrm{i}$ en «single combined

\footnotetext{
${ }^{14}$ Se Oliver Dörr og Kirsten Schmalenbach, Vienna Convention on the Law of Treaties, Berlin 2012 s. 523-525 for en detaljert analyse.

${ }^{15}$ For eksempel ICJ, LaGrand (Tyskland mot USA), dom, 27. juni 2001, avsnitt 99.

${ }^{16}$ For en detaljert analyse av hvilke bestemmelser i Wien-konvensjonen som anses som folkerettslig sedvanerett se Mark Villiger, Commentary on the 1969 Vienna Convention on the Law of Treaties, Leiden 2009.

17 ICJ, Arbitral Award of 31 July 1989 (Guinea-Bissau mot Senegal), dom, 21. november 1991, avsnitt 48.

18 ICJ, Territorial Dispute (Libya mot Chad), dom, 3. februar 1994, avsnitt 41.

${ }^{19}$ ICJ, Kasikili/Sedudu Island (Botswana mot Namibia), dom, 13. desember 1999, avsnitt 18 og 48, som eksplisitt bekrefter at artikkel 31 tredje ledd er folkerettslig sedvanerett.

${ }^{20}$ ICJ, Oil Platforms (Iran mot US A), dom, 6. november 2003, avsnitt 41 (om artikkel 31 første ledd bokstav c).

${ }^{21}$ For eksempel WTO appellate body, Japan - Taxes on Alcoholic Beverages II, WT/DS 8, 10-11/AB/R, Part D, 10-12

(1996); og China - Measures Affecting Trading Rights and Distribution Services for Certain Publications and Audiovisual Entertainment Products, WT/DS363/AB/R, avsnitt 348 (2009).

${ }^{22}$ For eksempel EMD, Golder mot Storbritannia, søkenummer 4451/70, dom 21. februar 1975 avsnitt 29 og EMD, Demir og Baykara mot Tyrkia, søkenummer 34503/97, storkammerdom 12. november 2008 avsnitt 65.

${ }^{23}$ Det har ICJ konkludert med direkte i Kasikili/Sedudu Island (Botswana mot Namibia), dom 13. desember 1999, avsnitt 18.

${ }^{24}$ Det er fremhevet for eksempel også av Anthony Aust, Modern Treaty Law and Practice, 3. utgave, Cambridge $2013 \mathrm{~s}$. 208 og Richard Gardiner, Treaty Interpretation, 2. utgave, Oxford 2015 s. 202.
} 
operation». Dette kom frem i en uttalelse fra FNs folkerettskommisjon som utarbeidet Wienkonvensjonen på 1960-tallet:

«The Commission, by heading the article ... in the singular [general rule of interpretation] ..., intended to indicate that the application of the means of interpretation in the article would be a single combined operation.) ${ }^{25}$ (Min utheving.)

Det betyr i praksis at en ikke kan basere tolkningen av en bestemmelse kun på den påståtte ordlyden til begrepene som er brukt, eller kun på traktatens angivelige formål. Dette følger dels av at momentene er inntatt i samme setning, jf. artikkel 31 første avsnitt, og at de ikke er delt opp i ulike avsnitt. Det ble gjort fordi man ønsket å sikre seg mot «excessive molecularization» ${ }^{26}$ av Wienkonvensjonens regler om traktatstolkning. Likevel vil jeg drøfte hver av de fire tolkningsmomentene separat nedenfor, slik at analysen og utredningen blir enklere og mer oversiktlig.

For det andre vil jeg innledningsvis fremheve at de fire elementene, som må tas hensyn til i enhver tolkning, kan føre til indre spenninger. Noen ganger vil en tolkning av ordlyden trekke i motsatt retning av hva en slutning i lys av konteksten eller formålet skulle tilsi. I slike tilfeller må traktatstolkeren avveie slutningene mot hverandre for å komme frem til den riktige løsningen. Dette er i tråd med prinsippet om god tro som er analysert mer i detalj i punkt 3.5 nedenfor. I drøftelsen som følger, vil noen eksempler på slike spenninger komme opp; og løsninger lagt til grunn av ulike domstoler vil bli analysert. I denne sammenheng vil det også vise seg at enkelte internasjonale domstoler primært vil legge seg på en tolkning basert på ordlyden (ordrett tolkning), ${ }^{27}$ mens andre internasjonale domstoler legger mer vekt på en tolkning i lys av formålet (teleologisk tolkning). ${ }^{28}$

\subsection{Ordlyd}

Det første elementet i hovedregelen krever at man utleder «the ordinary meaning» av de ord som tolkes. Det betyr at man skal finne den vanlige eller normale betydningen av ordet som er brukt. Et ord kan imidlertid ha mer enn én vanlig betydning, og meningsinnholdet kan også endre seg over tid. ${ }^{29}$ Et relativistisk syn på hermeneutikk ligger til grunn for artikkel 31 som i første avsnitt krever at traktatstolkeren skal finne «the ordinary meaning to be given in good faith to the terms of the treaty» (min utheving.) Med andre ord søker traktatstolkeren å finne frem til bestemmelsens vanlige og aktuelle betydning som også reflekterer traktatpartenes kollektive intensjon. En analyse av ordlyden er derfor første skritt for å fastslå akkurat den betydningen av traktatsteksten som partene

\footnotetext{
${ }^{25}$ FNs folkerettskommisjon, Draft Articles on the Law of Treaties - with Commentaries, 1966, kommentar til Artikkel 27-28, s. 219 (avsnitt $\quad$ 8) tilgjengelig her: http://legal.un.org/ilc/texts/instruments/english/commentaries/1 1 1966.pdf (sist besøkt: 28.05.2017).

${ }^{26}$ Gardiner, Treaty Interpretation (2015), s. 162.

${ }^{27}$ Dette er tilfellet med WTO klageinstans, se: Isabelle Van Damme, «Treaty interpretation by the WTO Appellate Body», European Journal of International Law, 2010 s. 605-648.

${ }^{28}$ Dette er tilfellet med menneskerettighetsdomstoler som EMD, men også den inter-amerikanske domstolen for menneskerettigheter, se for eksempel Alastair Mowbray, «The Creativity of the European Court of Human Rights», Human Rights Law Review, 2005 s. 57-79, David Harris mfl., The Law of the European Convention on Human Rights, 3. utgave, Oxford 2014 s.7-12, Laurence Burgorgue-Larsen og Amaya Úbeda de Torres, The Inter-American Court of Human Rights: Case Law and Commentary, Oxford 2011 s. 58-68, Lukas Lixinski, «Treaty Interpretation by the Inter-American Court of Human Rights: Expansionism at the Service of the Unity of International Law», European Journal of International Law, 2010 585-604.

${ }^{29}$ Nærmere om dette se punkt 4 nedenfor.
} 
mente den skulle ha. Dermed respekteres statens suverenitet i tolkningsprosessen. Som nevnt ovenfor er dette et viktig mål ved traktatstolkning. ${ }^{30}$

Samtidig skal det tas hensyn til hva slags traktat som tolkes når en bestemmer «the ordinary meaning» av et ord. Dette følger av ordlyden i artikkel 31 første avsnitt som ble sitert ovenfor. Det ble der henvist til den alminnelige betydningen som skal «be given to the terms of the treaty». ${ }^{31}$ (Min utheving.) Traktatstolkeren søker altså ikke å tolke ordenes betydning slik en lekmann ville gjort det, men slik en person som er rimelig informert om hele traktatsinnholdet ville gjort det. I tillegg viser dette at «the ordinary meaning» av et ord skal forstås i sammenheng med setningen som ordet inngår i og traktatsinnholdet for øvrig. ${ }^{32}$

I praksis er det vanlig å bruke generelle eller spesialiserte ordbøker for å bestemme «the ordinary meaning» av de ord som tolkes. Et eksempel på dette er Verdens handelsorganisasjons klageinstans' tolkning av uttrykket «benefit» som en del av definisjon av en «subsidy»:

«In addressing this issue, we start with the ordinary meaning of 'benefit'. The dictionary meaning of 'benefit' is 'advantage', 'good', 'gift', 'profit', or, more generally, 'a favourable or helpful factor or circumstance'. [The New Shorter Oxford English Dictionary, (Clarendon Press, 1993), Vol. I, p. 214; The Concise Oxford Dictionary, (Clarendon Press, 1995), p. 120; Webster's Third New International Dictionary (unabridged), (William Benton, 1966), Vol. I, p. 204.] Each of these alternative words or phrases gives flavour to the term 'benefit' and helps to convey some of the essence of that term. These definitions also confirm that the Panel correctly stated that 'the ordinary meaning of "benefit" clearly encompasses some form of advantage.' [Panel Report, para. 9.112]. Clearly, however, dictionary meanings leave many interpretive questions open.»33

Et annet eksempel kan vi finne i EMDs praksis. Eksempelet vil også vise at ordlydsfortolkningen alltid må ta hensyn til traktatens kontekst, noe som jeg også analyserer nærmere i punkt 3.3. I enkelte tilfeller kan dette føre til at «the ordinary meaning» av et ord ikke er så klar som man skulle tro ved første øyekast. I saken Luedicke, Belkacem and Koş mot Tyskland tolket EMD ordet «free». Domstolen mente at ordbøkenes definisjon av «free» var utvetydig, men fortsatte likevel med å undersøke om det var noe i traktatens kontekst som kunne lede til en annen tolkning av begrepet. Til slutt konkluderte imidlertid domstolen med at ordet måtte forstås etter sin utvetydige mening:

«The Court finds ... that the terms 'gratuitement'/'free' in Article 6 para. 3 (e) ... have in themselves a clear and determinate meaning. In French, 'gratuitement' signifies 'd'une manière gratuite, ... Similarly, in English, 'free' means 'without payment, gratuitous' (Shorter Oxford Dictionary), 'not costing or charging anything, given or furnished without cost or payment' (Webster's Third New International Dictionary). Consequently, the Court cannot but attribute to the terms 'gratuitement' and 'free' the unqualified meaning they ordinarily have in both of the Court's official languages: these terms denote neither a conditional remission, nor a temporary exemption, nor a suspension, but a once and for all exemption or exoneration. It nevertheless remains to be determined whether, as the Government contend, the context as well as the object and purpose of the provision in issue negative

\footnotetext{
${ }^{30}$ Malgosia Fitzmaurice, «The Practical Working of the Law of Treaties», i International Law, 3. utgave, Oxford $2010 \mathrm{~s}$. 183 og Dörr og Schmalenbach, Vienna Convention on the Law of Treaties (2012), s. 522.

${ }^{31}$ Det er fremhevet av Villiger, Commentary on the 1969 Vienna Convention on the Law of Treaties (2009), s. 426.

32 Se mer om konteksten i punkt 3.3 nedenfor.

${ }_{33}$ WTO Appellate Body, Canada - Measures Affecting the Export of Civilian Aircraft, Report AB-1999-2, 2. august 1999, WT/DS70/AB/R, s. 39, avsnitt 154. Gardiner, Treaty Interpretation (2015), s. 186-190, analyserer også dette og andre eksempler.
} 
the literal interpretation.» $\aleph^{34}$

Selv om det ikke er et hierarki mellom tolkningselementene, er det ofte slik at tolkningsprosessen starter med en analyse av ordlyden. ${ }^{35}$ Grunnen til dette er antakelsen om at det er ordlyden som i størst grad gir uttrykk for traktatpartenes kollektive intensjon med traktaten. Dessuten må en begynne tolkningsprosessen et sted, og ordlyden er et godt og logisk utgangspunkt. ${ }^{36}$

Ordlyden omfatter også den grammatiske tiden (tempus) som er brukt i bestemmelsen som tolkes. Et eksempel på at tidsformen ble vektlagt er CERD-saken (Georgia mot Russland), som ICJ avgjorde i 2008. ${ }^{37}$ Her måtte domstolen tolke uttrykket «is not settled», et uttrykk som er brukt i artikkel 22 i FNs konvensjon mot rasediskriminering. ${ }^{38}$ Spørsmålet var når en tvist mellom to parter til konvensjonen kunne prøves for den internasjonale domstolen. Det beror på uttrykket «is not settled». Må part A til konvensjonen forst prøve å løse en tvist med part B gjennom forhandlinger, før A kan bringe tvisten inn for den internasjonale domstolen? Eller behøver A ikke å forsøke å løse tvisten gjennom forhandlinger først? I FN-konvensjonen mot rasediskriminering artikkel 22 står det:

«Any dispute between two or more States Parties with respect to the interpretation or application of this Convention, which is not settled by negotiation or by the procedures expressly provided for in this Convention, shall, at the request of any of the parties to the dispute, be referred to the International Court of Justice for decision, unless the disputants agree to another mode of settlement.» (Min utheving.)

I avgjørelsen (preliminary objections) viste ICJ til tempus som er brukt i den engelske og franske teksten, og konkluderte med følgende:

«The Court also observes that, in its French version, the above-mentioned expression employs the future perfect tense, whereas the simple present tense is used in the English version. The Court notes that the use of the future perfect tense further reinforces the idea that a previous action (an attempt to settle the dispute) must have taken place before another action (referral to the Court) can be pursued. (19 $^{39}$ (Min utheving.)

Som vi ser var tidsformen viktig for domstolens tolkningsresultat. Domstolen avviste saken fordi Georgia ikke hadde forsøkt å løse tvisten med Russland før saken ble brakt inn for ICJ. ${ }^{40}$ Saken er i tillegg et eksempel på tolkning av en flerspråklig traktat. Tolkningen av flerspråklige traktater er analysert i detalj i punkt 6 .

\footnotetext{
${ }^{34}$ EMD, Luedicke, Belkacem og Koç mot Tyskland, søkenummer 6210/73, 6877/75 og 7132/75, dom 28. november 1978 avsnitt 40 .

${ }^{3}$ Se for eksepel ICJ, Legality of the Use of Force (Serbia og Montenegro mot Belgia), dom, 15. desember 2004, avsnitt 100.

${ }^{36}$ Gardiner, Treaty Interpretation (2015), s. 181.

${ }^{37} \mathrm{Se}$ ICJ, Application of the International Convention on the Elimination of All Forms of Racial Discrimination (Georgia mot Russland), Preliminary Objections, 1. april 2011 og Dörr og Schmalenbach, Vienna Convention on the Law of Treaties (2012), s. 542 som analyserer dette eksempelet.

${ }^{38} \mathrm{FN}$ konvensjonen mot rasediskriminering (Convention on the Elimination of All Forms of Racial Discrimination), vedtatt 21. desember 1965, trådt i kraft 4. januar 1969.

${ }^{39}$ ICJ, Application of the International Convention on the Elimination of All Forms of Racial Discrimination (Georgia mot Russland), Preliminary Objections, 1. april 2011, avsnitt 135.

${ }^{40}$ ICJ vil trolig komme tilbake til dette spørsmålet i en sak som Ukraina har lansert mot Russland i januar 2017. Se ICJ pressemelding: http://www.icj-cij.org/docket/files/166/19310.pdf.
} 


\subsection{Kontekst}

\subsubsection{Innledning}

Traktatsbestemmelser må tolkes i sin «context», jf. Wien-konvensjonen artikkel 31 første avsnitt. Traktatstolkning er derfor ikke en rent semantisk eller grammatisk øvelse. De som tolker traktaten må se på traktaten som en helhet. ${ }^{41}$ Av artikkel 31 andre avsnitt følger det at konteksten omfatter hele traktatsteksten inkludert traktatstittelen, fortalen (preambelet), eventuelle vedlegg og protokoller til traktaten. En må også ta hensyn til systematikken i traktaten, og hvordan uttrykket som tolkes står i denne systematikken. Det kan bety at man ser på bruk av ord i andre deler av traktaten, og slutter ut fra dette hvordan et annet uttrykk skal tolkes. ${ }^{42}$

Et godt eksempel, ${ }^{43}$ er Comprehensive Nuclear-Test-Ban Treaty fra 1996 artikkel 1 første avsnitt. ${ }^{44}$ Der står det:

«Each State Party undertakes not to carry out any nuclear weapon test explosion or any other nuclear explosion ...». (Min utheving.)

Hvis vi bare ser på denne artikkelen isolert fra andre bestemmelser i traktaten, kunne man tro at traktaten ikke bare forbyr testing av atomvåpen, men også bruk av atomvåpen. Hvis vi derimot tar hensyn til konteksten, kommer vi frem til et annet resultat. For eksempel viser traktatstittelen tydelig at traktaten kun regulerer testing av atomvåpen (Nuclear-Test-Ban Treaty). Videre er det i fortalen gjort helt klart at denne traktaten bare er ett skritt mot kjernefysisk nedrustning, ${ }^{45}$ og at den dermed ikke forbyr bruk av atomvåpen. Det ville heller ikke stater som USA, Russland, Frankrike, India og Pakistan blitt enige om i den politiske situasjonen vi hadde da Nuclear-TestBan treaty ble vedatt. En situasjon vi forsåvidt også har i dag.

Wien-konvensjonen artikkel 31 andre og tredje avsnitt redegjør for hva som nærmere følger av konteksten. Det skal jeg se nærmere på i det følgende.

\subsubsection{Artikkel 31 andre avsnitt: noen elementer av konteksten}

I Wien-konvensjonen artikkel 31 andre avsnitt står det:

«2. The context for the purpose of the interpretation of a treaty shall comprise, in addition to the text, including its preamble and annexes:

(a) any agreement relating to the treaty which was made between all the parties in connection with the conclusion of the treaty;

(b) any instrument which was made by one or more parties in connection with the conclusion of the treaty and accepted by the other parties as an instrument related to the treaty.»

Det fremgår av bokstav a) at «an agreement», som skal tas hensyn til som en del av konteksten, må bygge på en konsensus mellom alle parter. ${ }^{46}$ Den må også ha blitt vedtatt samtidig som traktaten. ${ }^{47}$ Dessuten følger det av ordlyden at den må tydelig forholde seg til traktatens innhold eller

\footnotetext{
${ }^{41}$ Dörr og Schmalenbach, Vienna Convention on the Law of Treaties (2012), s. 534.

42 Dörr og Schmalenbach, Vienna Convention on the Law of Treaties (2012), s. 534.

${ }^{43}$ Nevnt av Aust, Modern Treaty Law and Practice (2013), s. 2010.

${ }^{44}$ Comprehensive Nuclear-Test-Ban Treaty, ILM (1996) 1443, not entered into force yet in line with Article XIV (se: https://www.ctbto.org/map/\#status).

${ }^{45}$ I preamblet star det: «...Recognizing that an end to all $[\ldots]$ nuclear explosions will $[. .$.$] constitute a meaningful step in$ the realization of a systematic process to achieve nuclear disarmament» (min utheving).

${ }^{46}$ Dörr og Schmalenbach, Vienna Convention on the Law of Treaties (2012), s. 550 og Villiger, Commentary on the 1969 Vienna Convention on the Law of Treaties (2009), s. 429.

${ }^{47}$ Dörr og Schmalenbach, Vienna Convention on the Law of Treaties (2012), s. 550-551.
} 
prosedyrer fastsatt i traktaten. Det kreves imidlertid ikke at den aktuelle «agreement» må være en del av traktaten eller utgjøre en egen traktat. ${ }^{48}$ I slike «agreements» kan partene for eksempel gi uttrykk for sin intensjon om hvordan visse bestemmelser i en traktat skal tolkes, eller hvordan en traktat forholder seg til en annen traktat. Noen eksempler på slike «agreements» vil gjøre dette mer konkret: $^{49}$

- Først har vi «The Understandings with respect to certain provisions of the Convention» ${ }^{50}$ som ble vedlagt 2004 UN Convention on the Jurisdictional Immunities of States and their Property. ${ }^{51}$ I disse «Understandings» forklarer partene til FNs konvensjon om immunitet i detalj betydningen av enkelte begreper som brukes i traktaten.

- Et annet eksempel er «Chairman's Statement on Islands» ${ }^{52}$ som ble vedtatt sammen med The Convention for the Conservation of Antarctic Marine Living Resources i $1980 .{ }^{53}$ Det fremgår av Chairman's Statement at konvensjonen ikke får anvendelse på enkelte øyer under gitte betingelser. Chairman's Statement ble fremforhandlet sammen med konvensjonen, og ingen protesterte mot at den ble vedtatt sammen med konvensjonen.

- Et tredje eksempel er Explanatory Report, ${ }^{54}$ vedtatt av Ministerkomiteen til Europarådet da Komiteen vedtok The Criminal Law Convention on Corruption i 1999. ${ }^{55}$ Dette eksempelet viser at «agreements relating to the treaty» også kan være resolusjoner vedtatt av organer til internasjonale organisasjoner, i dette tilfellet Europarådets Ministerkomite.

Bokstav b) i artikkel 31 andre avsnitt viser til at «any instruments made by one or more parties» også kan regnes som en del av konteksten. Disse «instruments» kan være ensidige eller multilaterale forklaringer til traktaten eller til enkelte traktatsbestemmelser. Derimot må disse ensidige eller multilaterale «instruments», for å inngå som en del av konteksten, bli akseptert (eksplisitt eller stilliende) av alle de andre traktatspartene. ${ }^{56}$ Et godt eksempel på slike «instruments» finner vi i EUretten. ${ }^{57}$ Det er vanlig praksis i EU at en eller flere av medlemslandene vedlegger erklæringer til EU-traktatene, når disse blir vedtatt på EU-konferanser. ${ }^{58}$ På slutten av forhandlingene anerkjenner

\footnotetext{
48 Aust, Modern Treaty Law and Practice (2013), s. 211 og Dörr og Schmalenbach, Vienna Convention on the Law of Treaties (2012), s. 549.

${ }^{49}$ Eksempler er tatt fra Aust, Modern Treaty Law and Practice (2013), s. 211 og Dörr og Schmalenbach, Vienna Convention on the Law of Treaties (2012), s. 551-552.

${ }^{50}$ Vedlegg til UNGA Res 59/38, 16. desember 2004, UN Doc. A/RES/59/38.

${ }^{51}$ UN Convention on Jurisdictional Immunities of States and Their Property, UNGA Res 59/38, 16. desember 2004, UN Doc. A/RES/59/38, (ennå ikke trådt i kraft).

${ }^{52}$ Statement by the Chairman of the Conference on the Conservation of Antarctic Marine Living Resources er tilgjengelig her: www.ccamlr.org/en/organisation/camlr-convention-text\#Chair.

${ }^{53}$ Convention for the Conservation of Antarctic Marine Living Resources (CCAMLR), 1329 UNTS 57, vedtatt 20. mai 1980, trådt i kraft 7. april 1982.

54 Explanatory Report to the Criminal Law Convention on Corruption, ETS 173 (1999), tilgjengelig her: https://rm.coe.int/CoERMPublicCommonSearchServices/DisplayDCTMContent?documentId=09000016800cce44.

55 Criminal Law Convention on Corruption, ETS 173, vedtatt 27. januar 1999, trådt i kraft 1. juli 2002.

${ }^{56}$ Dörr og Schmalenbach, Vienna Convention on the Law of Treaties (2012), s. 552 og Villiger, Commentary on the 1969 Vienna Convention on the Law of Treaties (2009), s. 430.

${ }^{57}$ Legg merke til at EU-domstolen (the Court of Justice of the European Union) har utviklet sin egen tilnærming til å tolke og anvende VCLT i sin tolkning av EU-retten. Se den detaljerte analysen av Jed Odermatt, «The Use of Interantional Treaty Law by the Court of Justice of the European Union», Cambridge Yearbook of European Legal Studies, 2015, s. 121-144. I analysen som følger vil vi derfor ikke bruke rettspraksis fra CJEU som eksempel. Men dette eksluderer ikke at de nevnte erklæringer (se fotnote 58) kan anses som «any instruments made by one or more parties» etter artikkel 31 andre avsnitt bokstav b).

${ }^{58}$ For eksempel erklæringer i Final Act vedlagt Lisboa-traktaten (2007), [2007] OJ C 306, 231, 267 følgende.
} 
vanligvis de andre medlemsstatene slike erklæringer offisielt. ${ }^{59}$ Ensidige forklaringer til traktaten eller til enkelte traktatsbestemmelser ofte minner om reservasjoner til traktater. Men i motsetning til reservasjoner ${ }^{60}$ redegjør ensidige forklaringer kun for hvordan en traktatspart forstår en bestemmelse. Ved å gå frem slik får stater muligheten til i forkant å påvirke tolkningen av traktaten. Hvilket gjennomslag de får avhenger imidlertid av hvordan de øvrige traktatspartene stiller seg til dem.

\subsubsection{Artikkel 31 tredje avsnitt: momenter som det skal tas hensyn til sammen med konteksten}

Wien-konvensjonen artikkel 31 tredje avsnitt angir momenter som skal tas hensyn til sammen med konteksten. Det står der:

«3. There shall be taken into account together with the context:

(a) any subsequent agreement between the parties regarding the interpretation of the treaty or the application of its provisions;

(b) any subsequent practice in the application of the treaty which establishes the agreement of the parties regarding its interpretation;

(c) any relevant rules of international law applicable in the relations between the parties.»

Momentene nevnt $\mathrm{i}$ tredje avsnitt har samme betydning for tolkningen av en traktat som momentene nevnt $\mathrm{i}$ andre avsnitt, som jeg har nettopp analysert. ${ }^{61}$ Tanken bak bokstavene a) og b) er at gjennom «subsequent agreements» eller «subsequent practice» kan de (suverene) traktatspartene selv avklare eller utvikle traktatens innhold. Med andre ord er «subsequent agreements» og «practice» anerkjent som et tolkningsmoment fordi dette kan gi indikasjoner på hvordan tratktaten er forstått av partene. Materialet nevnt under bokstav c) skal tas hensyn til i tolkingsprosessen på bakgrunn av antagelsen om at statene ikke vil vedta traktater som strider mot deres rettigheter og plikter etter folkeretten for øvrig, herunder folkerettslig sedvanerett.

«Subsequent agreements» mellom traktatspartene nevnt under bokstav a) ligner «agreements» etter Wien-konvensjonen artikkel 31 andre avsnitt bokstav a). Den eneste forskjellen er at «subesquent agreements» er gjort $i$ ettertid, dvs. når som helst etter at traktaten ble vedtatt. ${ }^{62}$ Akkurat som «agreements», må «subsequent agreements» etter artikkel 31 tredje avsnitt bokstav a) ikke nødvendigvis være egne traktater. ${ }^{63}$ De må imidlertid vise at traktatspartene ønsket at innholdet til en «subsequent agreement» skal være grunnlaget for en enhetlig tolkning. ${ }^{64}$ «Subesequent agreements» kan dessuten gå lenger enn å uttrykke en felles tolkning av en traktatsbestemmelse: De kan også føre til endring av traktaten. I så fall anvendes artikkel 39-41 i Wien-konvensjonen om endring og modifisering av traktater. Dette gjelder også når Wien-konvensjonen anvendes på sedvanegrunnlag. Artikkel 39-41 innholdt noen innovasjoner på 1950- og 60-taller da konvensjonen ble utarbeidet, men artiklene ble enstemmig akseptert på konferansen om Wienkonvensjonen i 1968-69, og ingen stat har siden utfordret gyldigheten av reglene om endring og

\footnotetext{
${ }^{59}$ Flere eksempler på slike «instruments» fra andre rettsområder finnes i Aust, Modern Treaty Law and Practice (2013), s. 202.

${ }^{60}$ Regler om reservasjoner finnes i artikkel 19-23 i Wien-konvensjonen.

${ }^{61}$ Dörr og Schmalenbach, Vienna Convention on the Law of Treaties (2012), s. 553.

${ }^{62}$ Dörr og Schmalenbach, Vienna Convention on the Law of Treaties (2012), s. 553 og Gardiner, Treaty Interpretation (2015), s. 206.

${ }^{63}$ Aust, Modern Treaty Law and Practice (2013), s. 213. Aust gir også noen eksempler på hva «subsequent agreement»er s. 213-214.

${ }^{64}$ Gardiner, Treaty Interpretation (2015), s. 218.
} 
modifikasjon i disse artiklene. Reglene reflekterer derfor relativt nylig etablert sedvanerett. ${ }^{65}$ Ytterligere må man være klar over at det ikke alltid er mulig, ei heller nødvendig, å skille mellom en «subsequent agreement» som (bare) uttrykker en enhetlig tolkning og en «agreement» som endrer meningsinnholdet $\mathrm{i}$ en traktat $\mathrm{i}$ tråd med artikkel 39-41 i Wien-konvensjonen. Det er ofte en glidende overgang mellom disse to. ${ }^{66}$

Det er viktig å se nærmere på Wien-konvensjonen artikkel 31 tredje avsnitt bokstav b) «subsequent practice in the application of the treaty which establishes the agreement of the parties regarding its interpretation». «Subsequent practice» mellom traktatspartene kan ses på som et uttrykk for hvordan partene har oppfattet traktaten, og hvordan de mener den skal tolkes. Dette må det tas hensyn til i tolkningsprosessen. Tanken bak dette - og bak mange andre regler i folkerettslig traktatsrett - er at (suverene) stater alltid forblir herrer over egne traktater. Dette innebærer, innenfor visse grenser, fri tolkning og endring av traktater. ${ }^{67}$

Hva regnes som «subsequent practice»? I prinsippet er det hvilken som helst praksis, også inaktivitet, som knytter seg til oppfyllelsen av traktaten. Det kreves altså ikke at praksisen har en bestemt form. Vanligvis finner vi den i offisielle uttalelser, diplomatisk korrespondanse, offisielle pressemeldinger eller statenes stemmegivning på resolusjoner $\mathrm{i}$ internasjonale organisasjoner. Dessuten er nasjonal lovgivning og nasjonale rettsavgjørelser viktige uttrykk for etterfølgende praksis. ${ }^{68}$ Hvor mye vekt etterfølgende praksis tillegges i traktatstolkningsprosessen avhenger av om den er felles for partene, og om den er konsistent og varig, og dermed om den uttrykker enighet mellom dem om tolkningen. Det er derimot ikke nødvendig å vise at enhver traktatspart har vært involvert i en praksis - det er tilstrekkelig at alle traktatspartene har akseptert den. ${ }^{69}$ Og dette kan være en stilltiende aksept (tacit agreement), det vil si fravær av avvisning av en (konsistent og varig) praksis. $^{70}$

Det er ikke bare statspraksis som anses som relevant «subsequent practice». Det kan også være praksis fra internasjonale organisasjoner. Dette gjelder særlig for traktater som oppretter en internasjonal organisasjon. For å operere effektivt, anvender internasjonale organisasjoners organer ofte disse traktatene, som deretter kan bidra til å skape en praksis. ${ }^{71}$

Det å ta hensyn til etterfølgende praksis ved traktatstolkning har blitt svært vanlig. Ett eksempel kan gjøre dette mer konkret. ${ }^{72}$ Eksempelet gjelder FN-pakten artikkel 27 tredje avsnitt som blir tolket i lys av etterfølgende praksis fra FNs medlemsland og FNs organer. ${ }^{73}$ I artikkel 27 tredje avsnitt står det:

\footnotetext{
${ }^{65}$ For flere detaljer og referanser til ytterligere litteratur se Villiger, Commentary on the 1969 Vienna Convention on the Law of Treaties (2009) s. 516, 526 og 538.

${ }^{66}$ Ruud og Ulfstein, Innføring i folkerett (2011), s. 95-96.

${ }^{67}$ Dörr og Schmalenbach, Vienna Convention on the Law of Treaties (2012), s. 555 og Gardiner, Treaty Interpretation (2015), s. 242-245.

${ }^{68}$ Dörr og Schmalenbach, Vienna Convention on the Law of Treaties (2012), s. 555-556.

${ }^{69}$ Dörr og Schmalenbach, Vienna Convention on the Law of Treaties (2012), s. 556-557.

${ }^{70}$ Villiger, Commentary on the 1969 Vienna Convention on the Law of Treaties (2009), s. 431-432, inkludert en diskusjon av relevant rettspraksis om stille aksept i internasjonale domstoler.

${ }^{71}$ Dörr og Schmalenbach, Vienna Convention on the Law of Treaties (2012), s. 558.

${ }^{72}$ For flere eksempler, ikke bare om etterfølgende praksis fra internasjonale organisasjoner, se Dörr og Schmalenbach, Vienna Convention on the Law of Treaties (2012), s. 557-560; og Aust, Modern Treaty Law and Practice (2013), s. 215-216.

${ }^{73}$ Eksempelet er tatt fra Aust, Modern Treaty Law and Practice (2013), s. 215-216. For flere eksempler om etterfølgende praksis fra internasjonale organisasjoner se Dörr og Schmalenbach, Vienna Convention on the Law of Treaties (2012), s. $558-559$.
} 
«Decisions of the Security Council on all other [non-procedural] matters shall be made by an affirmative vote of nine members including the concurring votes of the permanent members ...». ${ }^{74}$ (Min utheving.)

Etter ordlyden må de fem faste medlemmene i FNs sikkerhetsråd avgi en bekreftende («affirmative») stemme for at rådet kan ta en beslutning. Imidlertid var praksisen i Sikkerhetsrådet fra så tidlig som 1946 å tolke «concurring» (enighet) som fravær av å stemme mot en beslutning. I praksis betyr dette at dersom et fast medlem ønsker å blokkere en beslutning, må medlemmet bruke sin vetorett. Det er ikke tilstrekkelig å avstå fra å stemme eller å være fraværende. Denne etterfølgende praksisen ble anerkjent og bekreftet av ICJ i en rådgivende uttalelse i 1971 hvor domstolen tolket FN-pakten artikkel 27 tredje avsnitt. ${ }^{75}$ Dette eksempelet viser også at en tolkning i lys av konteksten, som tar hensyn til «subsequent practice», kan gå foran en tolkning som i hovedsak er basert på ordlyden, i dette tilfellet av uttrykket «concurring votes».

Vi har flere andre eksempler på bruk av etterfølgende statspraksis i tolkningsprosessen, særlig i avgjørelser fra EMD. EMD ser ofte på nasjonal lovgiving som implementerer EMK i medlemslandene, og på tolkning og anvendelse av disse i nasjonale domstoler. Hvis EMD basert på dette kan identifisere en «europeisk konsensus», i relasjon til et spørsmål, vil domstolen ofte bygge tolkningen av konvensjonen på denne. ${ }^{76}$ Selv om EMD ikke er helt konsekvent $i$ anvendelsen og forklaringen av sin «europeisk konsensus»-doktrine, og har blitt kritisert for dette, ${ }^{77}$ bekrefter denne doktrinen at «subsequent practice» som en tolkning bygges på, ikke nødvendigvis må deles eksplisitt av alle traktatsparter. For EMD er det ofte nok å fastslå at et stort flertall parter til EMK er involvert i en lik praksis, og at ingen stat har fremført innvendinger. Dette er i overensstemmelse med det som er beskrevet ovenfor - at «agreement» eller «acceptance» kan uttrykkes gjennom en stilltiende aksept. ${ }^{78}$

Det siste vi må merke oss ved etterfølgende praksis, er at det er en glidende overgang mellom presisering og endring av en traktat gjennom statspraksis - akkurat som med «subsequent agreements» nevnt ovenfor. Det er ingenting $i$ veien for at statene gjennom sin praksis viser enighet om at en traktat grunnleggende er endret eller til og med bortfalt. ${ }^{79}$

Jeg kommer nå til bokstav c) i artikkel 31 tredje avsnitt. Det er en av de mer uklare bestemmelsene i Wien-konvensjonen. Bestemmelsen sier at «any relevant rules of international law applicable in the relations between the parties» kan tas hensyn til som et moment $\mathrm{i}$ fortolkningsprosessen. Bestemmelsen viser at folkerettssystemet som en helhet, er en del av konteksten til enhver

\footnotetext{
${ }^{74}$ Charter of the United Nations (FN-pakten), trådt i kraft 24. oktober 1945, 1 UNTS XVI.

${ }^{75}$ ICJ, Legal Consequences for States of the Continued Presence of South Africa in Namibia (South-West Africa) Notwithstanding Security Council Resolution 276 (1970), rådgivende uttalelse, 21. juni 1971, avsnitt 20-22.

${ }_{76}$ To av mange eksempeler er Bayatyan mot Armenia, søkenummer 23459/03, storkammerdom 7. juli 2011 og Christine Goodwin mot Storbritannia, søkenummer 28957/95, storkammerdom 11. juli 2002 avsnitt 84-85. Selvfølgelig kan en «europeisk konsensus» også gjenspeile tolking basert på ordlyden når betydningen av et ord har endret seg over tid (se nærmere om dette i avsnitt 4 nedenfor). Eksemplene illustrerer også koblingen mellom de ulike elementene som må tas hensyn til i enhver tolkning. EMD og andre internasjonale domstoler sier ofte ikke helt eksplisitt hvilket element de bygger sin tolkning på.

${ }^{77}$ For en omfattende diskusjon om den «europeiske konsensus»-doktrinen, se Luzius Wildhaber, Arnaldur Hjartarson og Stephen Donnelly, «No Consensus on Consensus? The Practice of the European Court of Human Rights», Human Rights Law Journal, 2013 s. 248-262, Kanstantsin Dzehtsiarou, European Consensus and the Legitimacy of the European Court of Human Rights, Cambridge 2015 og Elgesem, «Tolkning av EMK - Menneskerettsdomstolens metode» (2003), s. 216218.

${ }^{78}$ Men dette er et spørsmål som er også diskutert mye i akademisk litteratur, blant annet i litteraturen som er oppført i fotnote 77.

${ }^{79}$ Villiger, Commentary on the 1969 Vienna Convention on the Law of Treaties (2009), s. 432.
} 
folkerettslig traktat. ${ }^{80}$ Bokstav c) åpner dermed døren for en systematisk tilnærming til traktatstolkning, og er på denne måten tenkt som et virkemiddel for å hindre en «fragmentering» av folkeretten. ${ }^{81} \mathrm{I}$ internasjonal engelsk litteratur uttales det gjerne at artikkel 31 tredje avsnitt bokstav c) inneholder «the principle of systemic integration». ${ }^{82}$

Uttrykket «relevant rules of international law» inkluderer i utgangspunktet alle typer folkerettslige regler. Det kan være andre traktater, folkerettslig sedvanerett, resolusjoner fra FNs sikkerhetsråd eller alminnelige rettsgrunnsetninger. ${ }^{83} \mathrm{I}$ praksis tar noen internasjonale og nasjonale domstoler $\mathrm{i}$ tillegg hensyn til ikke-bindende dokumenter. ${ }^{84}$ EMD og ICJ viser for eksempel tidvis til ikkebindende dokumenter fra FNs menneskerettighetsorganer når de, eksplisitt eller implisitt, anvender artikkel 31 tredje avsnitt bokstav c) i sine tolkninger av EMK og andre traktater. ${ }^{85}$ EMD ser i tillegg ofte til dokumenter fra forskjellige organer under Europarådet. ${ }^{86}$

Det neste spørsmålet blir hvordan man avgjør hvilke follkerettslige regler som er «relevant» i det konkrete tilfellet. Først er det grunn til å merke seg at ordlyden er uklar. Det er lagt til grunn at traktatsbestemmelser som omhandler det samme tema eller spørsmål, som bestemmelsen som tolkes er «relevant». ${ }^{87}$ For eksempel blir internasjonale menneskerettighetskonvensjoner ofte tatt $\mathrm{i}$ bektraktning ved tolkningen av regionale menneskerettighetstraktater. ${ }^{88} \mathrm{Og}$ videre vil bestemmelser $\mathrm{i}$ internasjonal humanitærrett være relevant ved fastleggelsen av internasjonal strafferett. ${ }^{89}$ Dette er ikke overraskende fordi det først og fremst er i traktater og sedvaneregler fra samme rettsområde man finner mommenter av betydning for den foreliggende sak.

Men begrepet «relevant rules» avgrenser ikke mot at folkerettslige regler som omhandler noe annet, også tas hensyn til som en del av konteksten. En forutsetning er imidlertid at reglene kan bidra i tolkningen av traktatsbestemmelsen..$^{00}$ Dette kan eksempelvis være når de er skapt for å løse de samme eller lignende saklige, juridiske eller tekniske problemer som traktatsbestemmelsen som tolkes. ${ }^{91}$ Skal Wien-konvensjonen artikkel 31 tredje avsnitt bokstav c) kunne motvirke en

\footnotetext{
${ }^{80}$ Dörr og Schmalenbach, Vienna Convention on the Law of Treaties (2012), s. 560.

${ }^{81}$ Ruud og Ulfstein, Innforing i folkerett (2011), s. 95.

82 Se Fragmentation of International Law: Difficulties Arising from the Diversification and Expansion of International Law. Report of the Study Group of the International Law Commission finalised by Martti Koskenniemi, UN Doc. A/CN.4/L.682, 13 April 2006, avsnitt 479-480, Campbell Mclachlan, «The Principle of Systemic Integration and Article 31(3)(c) of the Vienna Convention», International and Comparative Law Quarterly, 2005 s. 279-319 og Dörr og Schmalenbach, Vienna Convention on the Law of Treaties (2012), s. 561.

83 Villiger, Commentary on the 1969 Vienna Convention on the Law of Treaties (2009), s. 433.

${ }^{84}$ Dörr og Schmalenbach, Vienna Convention on the Law of Treaties (2012), s. 564.

${ }^{85}$ EMD, Mamatkulov og Askarov mot Tyrkia, søkenummer 46827/99 og 46951/99, dom 4. febraur 2005 avsnitt 39-42 og 111-115, og på en indirekte måte, uten en eksplisitt henvisning Wien-konvensjonen artikkel 31 tredje avsnitt bostav c), Bayatyan mot Armenia, avsnitt 105 lest i sammenheng med den armenske regjeringens argumenter i avsnitt 61, og delvis dissenterende vota fra dommerne Rozakis, Tulkens, Kovler, Hajiyev, Spielmann og Hirvelä i Saadi mot Storbritannia, søkenummer 13229/03, storkammerdom 29. januar 2008, og ICJ, Ahmadou Sadio Diallo Republikken Guinea mot Den Demokratiske republikeken Kongo), dom, 30. november 2010, avsnitt 66-67 og 77.

86 Se sammendraget av EMDs relevante rettspraksis i Demir og Baykara mot Tyrkia, søkenummer 34503/97, storkammerdom 12. november 2008 avsnitt 74-75 lest i sammenheng med avsnitt 67.

${ }^{87}$ Villiger, Commentary on the 1969 Vienna Convention on the Law of Treaties (2009), s. 433 og Dörr og Schmalenbach, Vienna Convention on the Law of Treaties (2012), s. 565.

${ }^{88}$ For eksempel EMD, Nada mot Sveits, søkenummer 10593/08, storkammerdom 12. september 2012 avsnitt 169 og Demir og Baykara mot Tyrkia, avsnitt 67-69.

${ }^{89}$ Se for eksempel rettspraksis fra Det internasjonale krigsforbrytertribunalet for det tidligere Jugoslavia (ICTY), tilgjengelig på: http://www.icty.org/en/cases/judgement-list. Ett av svært mange eksempler: ICTY, The Prosecutor v. Ljube Boškoski and Johan Tarčulovski, IT-04-82-T, Judgement of 10 July 2008, avsnitt 175-292.

${ }^{90}$ Villiger, Commentary on the 1969 Vienna Convention on the Law of Treaties (2009), s. 432.

${ }^{91}$ Dörr og Schmalenbach, Vienna Convention on the Law of Treaties (2012), s. 565.
} 
fragmentering av folkeretten, er man tidvis nødt til ikke bare å se på regler om samme emne, men også på regler fra andre folkerettsområder som har felles berøringsflater med traktatsbestemmelsen som tolkes og anvendes på et konkret saksforhold. Vi har noen eksempler på dette, deriblant fra EMD, hvor domstolen har tatt hensyn til folkerettslige traktater om et annet emne i tolkningsprosessen av EMK, men hvor bestemmelsen likevel var relevant for det juridiske og saklige problemet som EMD behandlet. Et eksempel på dette er EMDs sak Al-Adsani mot Storbritannia. Klager hadde både kuwaitisk og britisk nasjonalitet. Mens han besøkte Kuwait endte han opp i et kuwaitisk fengsel hvor han ble utsatt for alvorlig tortur. Da han kom tilbake til Storbritannia, gikk han til sivilt søksmål mot kuwaitiske myndigheter for britiske domstoler. Britiske domstoler avviste saken fordi Kuwaits regjering er beskyttet av reglene om statlig immunitet. Han klaget deretter til EMD, og hevdet at hans rett på tilgang til en nasjonal domstol under EMK artikkel 6 første avsnitt hadde blitt krenket. Han fikk ikke medhold i EMD. EMD mente at:

«55. [T] he Convention has to be interpreted in the light of the rules set out in the Vienna Convention on the Law of Treaties of 23 May 1969, and that Article $31 \S 3$ (c) of that treaty indicates that account is to be taken of 'any relevant rules of international law applicable in the relations between the parties'. ... The Convention should so far as possible be interpreted in harmony with other rules of international law of which it forms part, including those relating to the granting of State immunity.

56. It follows that measures taken by a High Contracting Party which reflect generally recognised rules of public international law on State immunity cannot in principle be regarded as imposing a disproportionate restriction on the right of access to a court as embodied in Article $6 \rrbracket 1$. Just as the right of access to a court is an inherent part of the fair trial guarantee in that Article, so some restrictions on access must likewise be regarded as inherent, an example being those limitations generally accepted by the community of nations as part of the doctrine of State immunity..192 (Min utheving.)

EMD tolket her retten til å få prøvd sin sak for en nasjonal domstol i lys av de folkerettslige sedvaneregler om statlig immunitet. Klagerens rett til adgang for en nasjonal domstol etter EMK artikkel 6 første avsnitt ble betydelig begrenset på grunn av den systematiske fortolkningsmetode EMD anvendte. Bruk av «relevant rules of international law» etter artikkel 31 første avsnitt bokstav c) vil ofte også bidra med å finne en tolkning som er i samsvar med den nåværende utviklingen av folkeretten. ${ }^{93}$

Det er også viktig å fremheve at ikke alle internasjonale domstoler og tribunaler anvender artikkel 31 tredje avsnitt bokstav c) med samme åpenhet som EMD i Al-Adsani og andre saker. WTOs klageinstanser har for eksempel vært mye mer tilbakeholdne med å vektlegge folkerettslige regler utenfor WTO-retten i tolkningen av WTO-traktater. Et eksempel er EC - Biotech, hvor et WTOpanel nektet å ta hensyn til Convention on Biological Diversity og dens Cartagena Protocol on Biosafety $^{94}$ i sin tolkning av SPS-traktaten ${ }^{95}$ i samsvar med artikkel 31 tredje avsnitt bokstav c). Dermed unngikk panelet å ta hensyn til føre-var-prinsippet som var inntatt i konvensjonen og protokollen. Å legge vekt på føre-var-prinsippet ville ledet til en annen tolkning av SPS-traktaten,

\footnotetext{
92 EMD, Al-Adsani mot Storbritannia, søkenummer 35763/97, storkammerdom 21. november 2001 avsnitt 55-56.

${ }^{93}$ Se for eksempel ICJ Namibia-saken sitert nedenfor i punkt 4; og analysen av rettspraksisen av McLachlan, s. 293 følgende.

${ }^{94}$ Convention on Biological Diversity and its Cartagena Protocol on Biosafety, trådt i kraft 11. september 2003,2226 UNTS 128.

${ }_{95}$ Agreement on the Application of Sanitary and Phytosanitary Measures (SPS Agreement), trådt i kraft 1. januar 1995, 1867 UNTS 493.
} 
en tolkning som ville ha gitt mer oppmerksomhet til behovet for å beskytte miljøet og menneskers helse. Panelet kom til dette resultatet fordi det la til grunn en svært snever tolkning av Wienkonvensjonen artikkel 31 tredje avsnitt bokstav c): Panelet konkluderte med at artikkelen bare krevde «consideration of those rules of international law which are applicable between all parties to the treaty which is being interpreted». ${ }^{96}$ En slik forståelse vil medføre at Wien-konvensjonen artikkel 31 tredje avsnitt bokstav c) vil få svært liten betydning ved tolkningen av multilaterale traktater med mange traktatsparter. Den tolkningen er derfor avvist av for eksempel EMD ${ }^{97}$ og enkelte forfattere. ${ }^{98}$ Eksempelet viser at ulike internasjonale organer forstår bestemmelsene forskjellig på ulike rettsområder.

\subsection{Formål (effektivitet)}

Det tredje elementet i hovedregelen krever at traktatsbestemmelser tolkes slik at formålet eller formålene til traktaten blir fremmet. Dermed bringes det teleologiske eller funksjonelle elementet inn i tolkningsprosessen. ${ }^{99}$ For eksempel skal enhver tolkning som gjør deler av traktaten overflødig eller ineffektiv unngås. En slik tolkning kan, selv om den er basert på ordlyden og konteksten, kan tyde på at den er i strid med traktatens formål. Tolkning i lys av formålet har også en side til effektivitetsprinsippet. ${ }^{100}$

Wien-konvensjonen artikkel 31 første avsnitt henviser til traktatens «object and purpose». Uttrykket «object and purpose» $\mathrm{i}$ Wien-konvensjonen er et resultat av en referanse til den franske teksten $i$ ICJs rådgivende uttalelse om Folkemordkonvensjonen under utarbeidelsen av Wien-konvensjonen. ${ }^{101}$ I uttalelsen avgjorde ICJ hvorvidt det var tillatt å vedta reservasjoner til traktater i henhold til «l'objet et le but»av en traktat. ${ }^{102}$ «L'objet et le but» ble oversatt til «object and purpose» $\mathrm{i}$ den engelske versjonen av ICJs rådgivende uttalelse. Som påpekt av Dörr/Schmalenbach, hvis tatt bokstavelig, virker det som «l'objet» beskriver det materielle innholdet til en traktat, det vil si de rettigheter og plikter som skapes av traktaten, mens «le but» henviser til det generelle resultatet eller formålet som partene ønsker å oppnå med den. ${ }^{103}$ I praksis og $\mathrm{i}$ folkerettslæren er begge elementer imidlertid slått sammen til én test, hvor de som tolker traktaten henviser til formålet til hele traktaten eller til enkelte traktatsbestemmelser og dermed anvender det teleologiske eller funksjonelle tolkningsmomentet. ${ }^{104}$

\footnotetext{
${ }^{96}$ Panel Reports, European Communities - Measures Affecting the Approval and Marketing of Biotech Products, WT/DS291/R, Add.1 to Add.9 and Corr.1/WT/DS292/R, Add.1 to Add.9 and Corr.1/WT/DS293/R, Add.1 to Add.9 and Corr.1, adopted 21. November 2006, avsnitt 7.70 (min utheving).

${ }^{97}$ EMD, Demir og Baykara mot Tyrkia, avsnitt 78.

${ }^{98}$ Andrew Lang, «Twenty Years of the WTO Appellate Body's 'Fragmentation Jurisprudence'», Journal of International Trade Law and Policies, 2015 s. 116-125, på s. 119 og Gardiner, Treaty Interpretation (2015), s. 274.

${ }^{99}$ Dörr og Schmalenbach, Vienna Convention on the Law of Treaties (2012), s. 545.

100 Villiger, Commentary on the 1969 Vienna Convention on the Law of Treaties (2009), s. 428, inkludert henvisning til relevante rapporter fra FNs Folkerettskommisjon som var kraftig involvert i utarbeidelsen av Wien-konvensjonen. Se også Dörr og Schmalenbach, Vienna Convention on the Law of Treaties (2012), s. 547.

${ }^{101}$ Dörr og Schmalenbach, Vienna Convention on the Law of Treaties (2012), s. 546 og Gardiner, Treaty Interpretation (2015), s. 212.

102 ICJ, Reservations to the Convention on Prevention and Punishment of the Crime of Genocide, Advisory Opinion, 28 May 1951, s. 24.

${ }^{103}$ Dörr og Schmalenbach, Vienna Convention on the Law of Treaties (2012), s. 546 og Gardiner, Treaty Interpretation (2015), s. 213.

104 Dörr og Schmalenbach, Vienna Convention on the Law of Treaties (2012), s. 546 og Gardiner, Treaty Interpretation (2015), s. 214.
} 
Først må det tas stilling til hvordan vi avgjør hva som egentlig er en traktats formål. Noen traktater inneholder generelle bestemmelser som angir traktatens formål og da er oppgaven forholdsvis enkel. Et eksempel på dette er FN-paktens artikkel 1 hvori det gjøres rede for FNs formål og dermed også FN-paktens formål. ${ }^{105}$ Videre kan tittelen eller fortalen være nyttige for å utlede en traktats formål. I andre tilfeller kan det være mulig å bestemme formålet ved å se på hva slags traktat vi snakker om. Når vi for eksempel har en traktat som fastsetter grenser mellom stater kan vi slutte at formålet med traktaten er å regulere grensespørsmål. Men generelt må en ta hensyn til teksten i bele traktaten for trygt å kunne fastslå dens formål. ${ }^{106}$

Vi finner ofte referanser til en traktats formål og til effektivitetsprinsippet $\mathrm{i}$ tolkninger av menneskerettighetstraktater, og i tolkninger av traktater som oppretter internasjonale organisasjoner og gir dem visse fullmakter og oppgaver. ${ }^{107}$ Et eksempel for hver av disse følger nedenfor.

Først vil jeg trekke frem et eksempel fra menneskerettighetsområdet: EMD har ofte påpekt at EMKs sentrale formål er å beskytte individuelle menneskerettigheter og menneskeverdet, samt å sikre og fremme idealer og verdier som ligger til grunn for et demokratisk samfunn. Et eksempel er Svinarenko og Slyadnev mot Russland fra $2014 .{ }^{108}$ Saken dreide seg om det forhold at russiske straffetiltalte måtte sitte $\mathrm{i}$ et metallbur i rettssalen under rettssaken. Klagerne hevdet at dette var «degrading» behandling, noe som er forbudt etter EMK artikkel 3. ${ }^{109}$ Den russiske regjeringen var uenig i det. EMD var enig med klager, og viste til EMKs formål for å komme frem til denne forståelsen av ordet «degrading», et ord hvis «ordinary meaning» ikke er lett å fastlegge:

"[T] he Court reiterates that the very essence of the Convention is respect for buman dignity and that the object and purpose of the Convention as an instrument for the protection of individual human beings require that its provisions be interpreted and applied so as to make its safeguards practical and effective. It is therefore of the view that holding a person in a metal cage during a trial constitutes in itself having regard to its objectively degrading nature which is incompatible with the standards of civilised behaviour that are the hallmark of a democratic society - an affront to human dignity in breach of Article 3.»110 (Min utheving.)

Det andre eksempelet er ICJs uttalelser om kompetansen til FN i Reparation for Injuries-saken fra 1949. ${ }^{111}$ Spørsmålet var om FN kunne kreve erstatning for skader på FN-ansatte fra stater som, på den tiden, ikke var medlemmer av FN. Denne kompetansen fremgår ikke eksplisitt av FN-paktens ordlyd, men i den rådgivende uttalelsen Reparation for Injuries uttalte ICJ:

105 I FN-paktens artikkel 1 står det: «The Purposes of the United Nations are: (1) To maintain international peace and security $[\ldots]$; (2) To develop friendly relations among nations based on respect for the principle of equal rights and self-determination of peoples [...]; (3) To achieve international co-operation in solving international problems of an economic, social, cultural, or humanitarian character, and in promoting and encouraging respect for human rights and for fundamental freedoms for all without distinction as to race, sex, language, or religion; and (4) To be a centre for harmonizing the actions of nations in the attainment of these common ends.»

106 Dörr og Schmalenbach, Vienna Convention on the Law of Treaties (2012), s. 546 og Villiger, Commentary on the 1969 Vienna Convention on the Law of Treaties (2009), s. 428.

107 Villiger, Commentary on the 1969 Vienna Convention on the Law of Treaties (2009), s. 427-428.

${ }^{108}$ EMD, Svinarenko og Slyadnev mot Russland, søkenummer 32541/08 og 43441/08, storkammerdom 17. juli 2014.

${ }^{109}$ I EMK artikkel 3 står det: «No one shall be subjected to torture or degrading treatment or punishment.»

${ }^{110}$ EMD, Svinarenko og Slyadnev mot Russland, avsnitt 138.

111 Dette og andre eksempler er også nevnt av Dörr og Schmalenbach, Vienna Convention on the Law of Treaties (2012), s. 547. 
«Under international law, the Organization must be deemed to have those powers which, though not expressly provided for in the Charter, are conferred upon it by necessary implication as being essential for the performance of its duties.»112 (Min utheving.)

Denne saken viser at fokus på en traktats formål kan føre til at uskrevne fullmakter («implied powers») anses inkludert i en traktat som oppretter en internasjonal organisasjon. Dette kan være nødvendig for å sette organisasjonen i stand til å oppfylle sine oppgaver etter traktaten, i dette tilfellet FN-pakten.

Selvfølgelig har fortolkninger i lys av traktatens formål, med henvising til effektivitetsprinsippet, sine grenser. Disse grensene settes ofte av traktatbestemmelsens ordlyd. ${ }^{113}$ Et godt eksempel på dette er Pretty-saken som ble fremmet for EMD i 2002. Klageren led av MS, og sykdommen hennes var langt fremskreden. Hun ønsket en bekreftelse fra den britiske påtalemyndigheten om at hennes mann ikke ville bli straffeforfulgt dersom han ga henne aktiv dødshjelp. Etter engelsk rett kunne hun ikke få en slik bekreftelse. Hun klagde til EMD og hevdet blant annet at EMK artikkel 2, som verner retten til liv, også omfatter retten til selv å bestemme om man skal fortsette å leve. Med andre ord: Spørsmålet var om retten til aktiv dødshjelp kunne leses inn i retten til liv etter EMK artikkel 2. Hun fikk ikke medhold i EMD. En av årsakene til dette var at EMD i stor grad vektla ordlyden i sin tolkning av artikkel 2, og ikke hennes anførte formålsfortolkning. Med en (indirekte) henvisning til konvensjonens formål - å fremme (personlig) selvbestemmelse og å beskytte menneskeverdet ${ }^{114}$ - hevdet klager at EMK beskyttet enkeltmenneskers rett til selv å velge om en vil fortsette å leve eller ikke, det vil si at konvensjonen dermed ga henne rett til å dø for å slippe uunngåelig lidelse og ydmykelse. EMD uttalte imidlertid:

«Article 2 cannot, without a distortion of language, be interpreted as conferring the diametrically opposite right, namely the right to die; nor can it create a right to self-determination in the sense of conferring on an individual the entitlement to choose death rather than life.»115 (Min utheving.)

På andre rettsområder $\mathrm{i}$ folkeretten enn menneskerettigheter, humanitær rett og rett om internasjonale organisasjoner, er det mindre vanlig å legge stor vekt på teleologiske tolkningsmetoder. Et godt eksempel er praksis fra WTOs klageinstanser. Akademikere som analyserer rettspraksis derfra er stort sett enige om at disse instansene generelt foretrekker å innta en formalistisk tilnærming til tolkningen. Det vil si at de ved tolkningen av WTO-traktater legger større vekt på ordlyden enn på formålet. ${ }^{116}$ Eksempelvis fremkommer det i uttalelser fra WTOs ankeinstans (Appellate Body) at en henvisning til «object and purpose» kan brukes til å bekrefte og begrunne en tolkning basert på ordlyden, men at den ikke kan danne «an independent basis for

\footnotetext{
112 ICJ, Reparation for Injuries suffered in the Service of the United Nations, rådgivende uttalelse, 11. april 1949, s. 182.

113 Villiger, Commentary on the 1969 Vienna Convention on the Law of Treaties (2009), s. 428 og Dörr og Schmalenbach, Vienna Convention on the Law of Treaties (2012), s. 547.

114 EMD, Pretty mot Storbritannia, søkenummer 2346/02, dom 29. april 2002 avsnitt 35 og 44.

115 EMD, Pretty mot Storbritannia, avsnitt 39 og en lignende uttalelse fra Iran-United States Claims Tribunal, United States, Federal Reserve Bank of New York v Iran, Bank Markazi, Case A 28 (2000) 36 Iran-US Claims Tribunal Reports 5, avsnitt 58. Dette eksempelet er også nevnt av Dörr og Schmalenbach, Vienna Convention on the Law of Treaties (2012), s. 547. 116 Van Damme, «Treaty interpretation by the WTO Appellate Body» (2010), s. 631, Lang, «Twenty Years of the WTO Appellate Body's 'Fragmentation Jurisprudence'» (2015), s. 117-120 (Lang analyserer også Wien-konvensjonens artikkel 31 tredje avsnitt bokstav c). Han viser at bestemmelsen kan bidra til å fastlegge en traktats formål som samsvarer med folkerettens utvikling for øvrig).
} 
interpretation». ${ }^{117}$ Videre følger det av uttalelsene at en tolking av WTO-traktater må baseres «above all upon the text of the treaty». ${ }^{118}$

Generelt kan man legge til grunn at formålsfortolkning og effektivitetsprinsippet blir vektlagt i større grad i dag enn tidligere. På 1800-tallet og begynnelsen av 1900-tallet fulgte internasjonale domstoler heller det såkalte restriktive tolkningsprinsippet. Dette prinsippet tok sikte på å respektere staters suverenitet ved å foreskrive en innskrenkende fortolkning av traktater. ${ }^{119}$ Dette prinsippet er forlatt for lenge siden, selv når eldre traktater tolkes. Illustrerende er ICJs uttalelse fra 2009 i Costa Rica mot Nicaragua der domstolen tolket en traktat fra 1858. Domstolen var der tydelig på at man i dag tar sikte på å ivareta hensynet til en effektiv gjennomføring av traktater, altså effektivitetsprinsippet og traktatens formål, også i saker hvor man tolker traktatsbestemmelser som innskrenker statens suverenitet. ICJ fremhevet:

"While it is certainly true that limitations to the sovereignty of a state over its territory are not to be presumed, this does not mean that treaty provisions establishing such limitations ... should for this reason be interpreted a priori in a restrictive way. A treaty provision which has the purpose of limiting the sovereign powers of a state must be interpreted like any otherprovision of the treaty, i.e. in accordance with the intentions of its authors as reflected by the text of the treaty and the other relevant factors in terms of interpretation.»120 (Min uheving.)

\subsection{God tro}

Det siste elementet $i$ hovedregelen om traktatstolkning er prinsippet om god tro. Det er forankret i «good faith», jf. Wien-konvensjonen artikkel 31 første avsnitt. Prinsippet om god tro må følges under hele tolkningsprosessen, det vil si også når andre elementer og supplerende tolkningsmomenter blir anvendt. ${ }^{121}$ Derfor analyserer noen forfattere dette elementet ikke som et eget, frittstående element, men mer som et tverrgående element. Jeg vil likevel drøfte prinsippet i et eget punkt. Årsaken til det er at prinsippet også krever at det endelige tolkningsresultatet er i overensstemmelse med «good faith», jf. Wien-konvensjonen artikkel 31 første avsnitt. ${ }^{122}$ Det gjør det etter min mening hensiktsmessig med en behandling av temaet $\mathrm{i}$ et eget punkt.

Selv om de internasjonale domstolene pleier å fremheve viktigheten av prinsippet om god tro, er det vanskelig å gi et presist innhold til prinsippet generelt. ${ }^{123} \mathrm{I}$ hovedsak krever prinsippet at enhver tolkning av en traktat blir gjennomført lojalt. Det vil si at den blir gjennomført uten spissfindighet og knep (forbudet mot misbruk og plikt til å avstå fra å ta urimelig fordel på bekostning av øvrige traktatsparter), at den hedrer legitime forventninger til andre traktatsparter, at alle deler av traktaten gir mening (effektivitet), og at den skal føre til et rimelig og fornuftig resultat. ${ }^{124}$ Det sistnevnte betyr at hvis fortolkningen av klare og tydelige ord i traktaten fører til et åpenbart urimelig resultat,

\footnotetext{
117 Appellate Body Report, Japan - Taxes on Alcoholic Beverages, WT/DS8/AB/R, WT/DS10/AB/R, WT/DS11/AB/R, 4 October 1996, s. 12, n. 20.

118 Appellate Body Report, Japan - Taxes on Alcoholic Beverages s. 11; se også de andre avgjørelsene fra WTOs ankeinstans nevnt av Van Damme, «Treaty interpretation by the WTO Appellate Body» (2010), s. 632.

${ }^{119}$ Dette er fremhevet av Ruud og Ulfstein, Innforing i folkerett (2011), s. 93.

${ }^{120}$ ICJ, Dispute Regarding Navigational and Related Rights (Costa Rica mot Nicaragua), dom, 13. juli 2009, avsnitt 48.

${ }^{121}$ Dörr og Schmalenbach, Vienna Convention on the Law of Treaties (2012), s. 548.

122 Dörr og Schmalenbach, Vienna Convention on the Law of Treaties (2012), s. 548.

${ }^{123}$ Dörr og Schmalenbach, Vienna Convention on the Law of Treaties (2012), s. 548 og Gardiner, Treaty Interpretation (2015), s. 168. Grunnen til dette er fordi det kan være vanskelig å bevise at en avgjørelse ble tatt i ond tro.

${ }^{124}$ Knut Ipsen, Völkerrecht, 4. utgave, München 2004 s. 146, Villiger, Commentary on the 1969 Vienna Convention on the Law of Treaties (2009), s. 425-426 (med henvisninger til rettspraksis), og Dörr/Schmalenbach, s. 548-549 og Gardiner, Treaty Interpretation (2015), s. 168.
} 
vil man i unntakstilfeller måtte velge en annen fortolkning. ${ }^{125}$ Ett eksempel på dette er måten begrepene «Republic of China» og «Union of the Socialist Republics» er tolket. ${ }^{126}$ Disse begrepene fremgår av FN-pakten artikkel 23 første avsnitt, hvor det står at:

«The Republic of China, the Union of Soviet Socialist Republics, France, the United Kingdom of Great Britain and Northern Ireland and the United States of America shall be permanent members of the Security Council.» (Min utheving.)

Da regjeringen til Republikken Kina i 1971 ble erstattet av regjeringen til Folkerepublikken Kina, var det ikke ansett nødvendig å endre uttrykket i artikkel 23 første avsnitt fra «Republic of China» til «People's Republic of China». Det samme gjelder for «Union of Soviet Socialist Republics», som ble erstattet med den Russiske Føderasjon i 1991. Ettersom FN-pakten artikkel 23 første avsnitt aldri har blitt endret, må man forstå «Republic of China» som «People’s Republic of China», og «Union of Soviet Socialist Republics» som «Russian Federation» i dag. Dette er en tolkning av artikkel 23 første avsnitt i god tro. En tolkning basert på «the ordinary meaning» av disse navnene ville føre til et urimelig og ufornuftig resultat.

Dette eksemplet viser at det er lett å forstå prinsippets praktiske betydning i nokså ekstreme tilfeller hvor et tolkningsresultat basert på ordlyden ville ført til et absurd resultat. Det er vanskeligere å fastlegge prinsippets praktiske funksjon i mindre spesielle tilfeller. Et eksempel har vi imidlertid fra WTOs klageinstans, USA - Shrimp. ${ }^{127}$ Der anvendes prinsippet om god tro for å komme frem til et tolkningsresultat som avveier traktatspartenes plikter og rettigheter på en rimelig og balansert måte. I saken brukte WTOs ankeorgan (Appellate Body) prinsippet om god tro ved tolkningen av The General Agreement on Tariffs and Trade (GATT) ${ }^{128}$ artikkel XX. Det er en bestemmelse som tillater WTO-medlemmer å innføre tiltak som ellers vil være i strid med forpliktelsene etter GATT. USA hadde vedtatt en ordning for å begrense import av reker fra stater som ikke sikret tilstrekkelig vern mot tilfeldig fangst av havskilpadder under kommersiell innhøsting ved bruk av tråler. GATT artikkel XX tillater unntak som er nødvendig for å verne «human, animal, or plant life or health» og unntak som gjelder «the conservation of exhaustible natural resources». ${ }^{129}$ Begge disse unntakene er imidlertid oppført etter en slags åpningsklausul («chapeau») som krever at unntakstiltak ikke skal anvendes «in a manner which would constitute a means of arbitrary or unjustifiable discrimination between countries where the same conditions prevail, or a disguised restriction on international trade». ${ }^{130}$ Ved tolkningen av disse bestemmelsene uttalte WTOs ankeorgan at:

«158. The chapeau of Article XX is, in fact, but one expression of the principle of good faith. This principle, at once a general principle of law and a general principle of international law, controls the exercise of rights by states. One application of this general principle, the application widely known as the doctrine of abus de droit, prohibits the abusive exercise of a state's rights and enjoins that whenever the assertion of a right 'impinges on the field covered by [a] treaty obligation, it must be exercised

\footnotetext{
125 Aust, Modern Treaty Law and Practice (2013), s. 208-209 og Dörr og Schmalenbach, Vienna Convention on the Law of Treaties (2012), s. 548.

126 Dette eksempelet er brukt også av Aust, Modern Treaty Law and Practice (2013), s. 209 og Dörr og Schmalenbach, Vienna Convention on the Law of Treaties (2012), s. 549.

127 United States - Import Probibition of Certain Shrimp and Shrimp Products, WTO Report of Appellate Board AB-1998-4, WT/DS58/AB/R, 12 October 1998.

128 GATT, 1994, 1867 UNTS 187.

${ }^{129}$ GATT artikkel XX, bokstav b) og g).

${ }^{130}$ GATT artikkel XX, chapeau.
} 
bona fide, that is to say, reasonably. ${ }^{\prime 131}$ An abusive exercise by a Member of its own treaty right thus results in a breach of the treaty rights of the other Members and, as well, a violation of the treaty obligation of the Member so acting. Having said this, our task here is to interpret the language of the chapeau, seeking additional interpretative guidance, as appropriate, from the general principles of international law. ${ }^{132}$

159. The task of interpreting and applying the chapeau is, hence, essentially the delicate one of locating and marking out a line of equilibrium between the right of a Member to invoke an exception under Article XX and the rights of the other Members under varying substantive provisions (eg Article XI) of the GATT 1994 so that neither of the competing rights will cancel out the other and thereby distort and nullify or impair the balance of rights and obligations constructed by the Members themselves in that Agreement.»133 (Min utheving.)

Som omtalt i detalj av Gardiner støtter internasjonale domstoler seg ofte på prinsippet om god tro i tre andre tilfeller: 1) Når de ønsker å poengtere at deres tolkning er i samsvar med effektivitetsprinsippet, 2) når de begrenser makten til en part ved å tolke en traktat på en bestemt måte, og 3) når de påberoper seg det generelle rimelighetsprinsippet (principle of reasonableness). ${ }^{134}$

\section{Det temporale elementet og den utviklingspregede tolkningsstilen}

Et annet spørsmål, som ofte oppstår ved tolkning av traktater, er hva skal en gjøre i tilfeller der betydningen av et ord har endret seg over tid.

Generelt må man, for å respektere partenes intensjoner (et utslag av statens suverenitet), ta utgangspunkt i ordenes betydning da traktaten ble inngått. ${ }^{135}$ ICJ og andre regionale domstoler bruker imidlertid også en dynamisk tilnærming ved tolkningen av begreper hvor meningsinnholdet endres over tid (den utviklingspregede tolkningsstil). Dette gjøres særlig når det kan antas at traktatspartene brukte ord som per definisjon utvikler seg over tid, såkalte «generic terms». ${ }^{136}$

ICJ anvendte den utviklingspregede tolkningsstilen først i 1971 i Namibia-saken. I saken tolket ICJ uttrykket «sacred trust» i Folkeforbundspakten fra 1919:

«Mindful as it is of the primary necessity of interpreting an instrument in accordance with the intention of the parties at the time of its conclusion, the Court is bound to take into account the fact that the concepts embodied in Article 22 of the Covenant [of the League of Nations] - 'the strenuous conditions of the modern world' and 'the well-being and development' of the peoples concerned were not static, but were by definition evolutionary, as also, therefore was the concept of 'sacred trust [of civilisation]'. The parties to the Covenant must consequently be deemed to have accepted them as such.»137 (Min utheving.)

\footnotetext{
131 Ankeorganet siterer her B. Cheng, General Principles of Law as applied by International Courts and Tribunals (Stevens and Sons, Ltd., 1953), Chapter 4, in particular, p. 125.

132 Ankeorganet inkluderer en fotnote her: Vienna Convention, Article 31(3)(c).

133 United States - Import Probibition of Certain Shrimp and Shrimp Products, WTO Report of Appellate Board AB-1998-4, WT/DS58/AB/R, 12 October 1998, avsnitt 158-59.

134 Gardiner, Treaty Interpretation (2015), s. 172-181.

135 Dörr og Schmalenbach, Vienna Convention on the Law of Treaties (2012), s. 534.

${ }^{136}$ Dörr og Schmalenbach, Vienna Convention on the Law of Treaties (2012), s. 534; for en mer detaljert analyse på norsk, se også Bjørge, «Dynamisk tolkning i den generelle folkeretten» (2012), s.112-118.

${ }^{137}$ ICJ, Legal Consequences for States of the Continued Presence of South Africa in Namibia, rådgivende uttalelse, avsnitt 53.
} 
Eksempelet viser at ord og uttrykk som «sacred trust [of civilisation]», «the strenuous conditions of the modern world» eller «the well-being and development of the peoples» utvikler seg over tid, og at de dermed er generiske begreper. I tillegg peker ICJ på at partene i Folkeforbundspakten var klar over dette da de vedtok pakten, og at en dynamisk tolkning av uttrykkene derfor ikke var i strid med intensjonene til traktatspartene. Det finnes mange andre eksempler på generiske ord hvor betydningen har endret seg over tid, og som derfor har blitt tolket dynamisk. Noen flere eksempler er:

- «natural resources», «sound recording» og «distribution» i WTO-retten, ${ }^{138}$

- «private life», ${ }^{139}$ «family life», ${ }^{140}$ «slavery and forced labour» ${ }^{141}$ og «inhuman and degrading treatment or punishment», ${ }^{142}$ i EMK,

- «grave breaches»/ «war crimes», ${ }^{143}$ «torture», ${ }^{144}$ «nationality» ${ }^{145} \mathrm{i}$ den humanitære folkeretten.

Vi finner dynamisk tolkning av (generiske) ord og begreper på ulike folkerettsområder. ${ }^{146}$ Men de mange eksemplene fra menneskerettighetsområdet viser at det er spesielt vanlig ved tolkning av menneskerettighetskonvensjoner. ${ }^{147}$ Dette illustreres av EMD som kaller den europeiske menneskerettighetskonvensjonen «a living instrument». ${ }^{148}$ Det er spesielt viktig for en effektiv beskyttelse av menneskerettighetene at domstoler tar hensyn til eksempelvis skiftende sosiale, politiske, religiøse og etiske forhold når de tolker og anvender internasjonale menneskerettighetskonvensjoner. Det fremmer dessuten formålet med menneskerettighetstrakteter: beskyttelse av menneskeverdet. WTOs klageinstanser tolker derimot sjelden WTO-retten dynamisk. Det har sammenheng med deres tilbakeholdenhet mot å bruke teleologiske tolkningsmetoder. ${ }^{149}$

Dynamisk tolkning er videre sterkt knyttet til tolkning i lys av etterfølgende praksis som ble diskutert tidligere i punkt 3.3.3. En endring i betydningen av ord og uttrykk manifesterer seg ofte i etterfølgende praksis. Dette er særlig tydelig i EMDs praksis som ofte knytter dynamisk tolkning opp mot eksistensen av en «europeisk konsensus». Etterfølgende statspraksis kommer gjerne til uttrykk gjennom en europeisk konsensus. ${ }^{150}$

For å oppsummere det temporale elementet: For å finne ut om et begrep skal tolkes dynamisk eller statisk, må en finne ut om begrepet er «generisk» og dermed per definisjon er ment å utvikles eller

138 Dörr og Schmalenbach, Vienna Convention on the Law of Treaties (2012), s. 534, hvor de analyserer WTO-rettspraksis.

${ }^{139}$ For eksempel E.B. mot Frankrike, søkenummer 43546/02, storkammerdom 22. januar 2008 avsnitt 92-98 og Dudgeon mot Storbritannia, søkenummer 7525/76, dom 22. oktober 1981 avsnitt 60-62.

${ }^{140}$ For eksempel X og Andre v. Østerrike, søkenummer 19010/07, storkammerdom 19. februar 2013 avsnitt 139.

${ }^{141}$ For eksempel Rantsev mot Kypros og Russland, søkenummer 25965/04, dom 7. januar 2010 avsnitt 275-282.

${ }^{142}$ For eksempel Tyrer mot Storbritannia, søkenummer 5856/72, dom 25. april 1978 avsnitt 31.

${ }^{143}$ ICTY (Appeals Chamber), Prosecutor v. Duško Tadic, Decision on the Defence Motion for Interlocutory Appeal on Jurisdiction, Case No. IT-94-1-AR72, 2. oktober 1995.

${ }^{144}$ ICTY (Trial Chamber), Prosecutor v. Zejnil Delalić, Zdravko Mucić, Hazim Delić and Esad Landžo, Case No. IT-96-21-T, 16. november 1998, avsnitt 475-497 (rape as torture).

${ }^{145}$ ICTY (Appeals Chamber), Prosecutor v. Duško Tadić, IT-94-1-A, judgement, 15. juli 1999, avsnitt 166.

146 Se analysen av Bjørge, «Dynamisk tolkning i den generelle folkeretten» (2012), s. 104-122.

${ }^{147}$ Dynamisk tolkning av EMK har blitt analysert mye i akademisk litteratur, se for eksempel Alastair Mowbray, «Between the Will of the Contracting Parties and the Needs of Today: Extending the Scope of Convention Rights and Freedoms beyond What Could Have Been Foreseen by the Drafters of the ECHR», i Shaping the Rights in the ECHR, Cambridge 2013 s. 17-37.

148 «Living instrument» doktrinen ble først utviklet av EMD i Tyrer-saken i 1978: Tyrer mot Storbritannia, søkenummer 5856/72, dom 25. april 1978 avsnitt 31 og har senere blitt gjentatt i utallige dommer.

149 Se analysen ovenfor, avsnitt 3.4.

${ }^{150}$ Se for eksempel saker fra EMD nevnt ovenfor i note 76. 
ikke. «Generiske» begreper omtaler en klasse av enheter eller aktiviteter. Dette er tilfellet med mange begreper som er brukt i folkerettslige traktater. "Generiske» begreper skilles fra «ikkegeneriske» begreper, dvs. fra individuelle («singulan») eller generelle («general») begreper. ${ }^{151}$ Eksempler på individuelle begreper som vanligvis tolkes statisk er navn til geografiske landmerker som elver, øyer eller fjell; generelle begreper er for eksempel «state parties» eller «third state». ${ }^{152} \mathrm{I}$ tillegg er det viktig å undersøke om en dynamisk tolkning fremmer en traktatbestemmelses formål.

\section{Supplerende tolkningsmomenter (Wien-konvensjonen artikkel 32)}

Wien-konvensjonen artikkel 32 inneholder supplerende tolkningsmomenter som kan tas i betraktning for å bekrefte («confirm») en tolkning i samsvar med artikkel 31, eller, i meget sjeldne tilfeller, for å avgjøre («determine») resultatet av tolkningen dersom tolkningsmomentene i artikkel 31 ikke fører til en klar løsning eller løsningen åpenbart er absurd eller urimelig:

«Recourse may be had to supplementary means of interpretation, including the preparatory work of the treaty and the circumstances of its conclusion, in order to confirm the meaning resulting from the application of Article 31, or to determine the meaning when the interpretation according to Article 31:

(a) leaves the meaning ambiguous or obscure; or

(b) leads to a result which is manifestly absurd or unreasonable.»1153

At tolkningsmomentene i artikkel 32 er supplerende, innebærer at deres anvendelsesområde er snevrere enn artikkel 31: Supplerende tolkningsmomenter bør normalt ikke brukes som alternative og autonome elementer i tolkningsprosessen, men bare for å bekrefte en tolkning etter artikkel 31 .

Supplerende tolkningsmomenter, som kan bekrefte (eller avgjøre) en tolkning, inkluderer traktatens forarbeider («preparatory work») og forhistorie («circumstances of its conclusion»). ${ }^{154}$ Det er ingen anerkjent definisjon i folkeretten av «preparatory work», og det er derfor heller ingen klar avgrensning av hva slags materiale som kan tas hensyn til i denne sammenheng. ${ }^{155}$ Forarbeider til traktater kan være av svært forskjellig karakter. Generelt anses alle dokumenter som statene har skapt og innhentet da de utarbeidet og forhandlet frem traktaten, som en del av forarbeidene. ${ }^{156}$ Blant disse er traktatsutkast, memoranda, kommentarer eller andre uttalelser som regjeringer har sendt til andre lands regjeringer eller til en traktatsutarbeidelseskomité. I tillegg er diplomatiske utvekslinger mellom forhandlingspartene og forhandlingsprotokoller relevante å ta i betraktning. Endringer og forslag til endringer av traktaktsteksten under forhandlingsprosessen er også en del av forarbeidene. ${ }^{157}$ Dessuten kan omfattende utredninger fra FNs folkerettskommisjon eller en annen uavhengig ekspertkomité regnes som en del av forarbeidene. ${ }^{158}$ Et krav er selvsagt at alle disse dokumentene må ha vært tilgjengelig for alle traktatspartene under traktatforhandlingene, ${ }^{159}$

\footnotetext{
${ }^{151}$ For en nærmere omtale av disse nyansene se Sondre Torp Helmersen, «Evolutive Treaty Interpretation: Legality, Semantics and Distinctions», European Journal of Legal Studies, 2013 s. 177-180.

${ }_{152}$ Gardiner, Treaty Interpretation (2015), s.191-192 med eksempler og Helmersen, «Evolutive Treaty Interpretation: Legality, Semantics and Distinctions» (2013), s. 180.

153 Wien-konvensjonen artikkel 32.

154 Villiger, Commentary on the 1969 Vienna Convention on the Law of Treaties (2009), s.445 og Dörr og Schmalenbach, Vienna Convention on the Law of Treaties (2012), s. 574-580.

155 Dörr og Schmalenbach, Vienna Convention on the Law of Treaties (2012), s. 574.

156 Villiger, Commentary on the 1969 Vienna Convention on the Law of Treaties (2009), s. 445 og Aust, Modern Treaty Law and Practice (2013), s. 245.

${ }^{157}$ Dörr og Schmalenbach, Vienna Convention on the Law of Treaties (2012), s. 574-577.

158 Aust, Modern Treaty Law and Practice (2013), s. 218 og Dörr og Schmalenbach, Vienna Convention on the Law of Treaties (2012), s. 576 med eksempler fra ICJs rettspraksis.

${ }^{159}$ Dörr og Schmalenbach, Vienna Convention on the Law of Treaties (2012), s. 576.
} 
også for de traktatspartene som senere slutter seg til en traktat. ${ }^{160}$ Dette utelukker konfidensielle dokumenter fra forarbeidene.

Forarbeidens vekt varierer. Det er flere momenter som spiller inn her. For det første har det betydning hvor klare de er. For det andre er tilknytningen til bestemmelsen som tolkes av interesse. Videre vil det kunne øke vekten, dersom flere ulike forarbeider gir uttrykk for det samme. Materialet må være sammenhengende nok til å kunne bidra med å fastsette traktatpartenes felles intensjoner og meningen de ønsket å gi til et ord eller artikkel i traktaten. ${ }^{161} \mathrm{Og}$ avslutningsvis kan det ha noe si hvor mange parter som har vært med å utarbeide forarbeidene, samt hvordan øvrige traktatsparter har stilt seg til materialet. ${ }^{162}$ Når det er sagt, kan forarbeider til traktater være ufullstendige, misvisende eller lite tilgjengelige, særlig når traktaten er multilateral. ${ }^{163}$ Grunnen til dette er at multilaterale traktatsforhandlinger ofte er kompliserte og langvarige, og til tider kaotiske. Dessuten kan noen traktatsbestemmelser være et resultat av kompromisser forhandlet frem i stor hast ved slutten av prosessen, og som dermed ikke gjenspeiles i forarbeidene. I slike tilfeller kan man ikke legge stor vekt på forarbeidene under tolkningsprosessen, og man er minnet om at forarbeider bare er et supplerende tolkningsmoment etter Wien-konvensjonen. ${ }^{164}$ Dette skiller reglene for tolkning av folkerettslige traktater fra norsk juridisk metode hvor det ofte legges stor vekt på forarbeidene til norske lover. I folkeretten er forarbeidene, som nevnt, ikke selvstendige tolkningsmomenter og må derfor brukes med varsomhet. ${ }^{165}$

Traktatens forhistorie («circumstances of the conclusion of a treaty») er et annet supplerende tolkningsmoment som kan tas i betraktning på samme måte som forarbeidene. Dette gjør det mulig å se på de historiske omstendighetene rundt forhandlingene og inngåelsene av traktatene, ${ }^{166}$ herunder politiske, kulturelle og sosiale faktorer og omstendigheter. ${ }^{167}$ Fremfor alt kan kunnskap om de historiske omstendighetene bidra til å identifisere og bekrefte partenes (historiske) motiver med traktaten, og dermed formålet med traktaten. ${ }^{168}$

Traktatens forarbeider og forhistorie er de praktisk viktigste tolkningsmomentene i artikkel 32. De er imidlertid ikke en uttømmende angivelse av hva artikkel 32 åpner for å trekke inn i tolkningsprossesen som supplerende momenter. Dette følger av begrepet «including». Den nærmere grensen for hva annet som kan trekkes inn er ikke autoritativt avgjort i praksis eller i folkerettslæren. ${ }^{169}$ Med hensyn til Wien-konvensjonens kontekst er det argumentert for i teorien at

\footnotetext{
${ }^{160}$ Dörr og Schmalenbach, Vienna Convention on the Law of Treaties (2012), s. 576. Forfatterne gir også eksempler hvor ICJ har brukt forarbeider til å fastlegge en stats traktatsforpliktelser, selv om staten først sluttet seg til traktaten i ettertid og derfor ikke var med under forhandlingene. Noe annet ville i praksis ført til vanskeligheter.

${ }^{161}$ Sml. Dörr og Schmalenbach, Vienna Convention on the Law of Treaties (2012), s. 575 og Villiger, Commentary on the 1969 Vienna Convention on the Law of Treaties (2009), s. 446.

162 Villiger, Commentary on the 1969 Vienna Convention on the Law of Treaties (2009), s. 446 og Dörr og Schmalenbach, Vienna Convention on the Law of Treaties (2012), s. 577.

163 Aust, Modern Treaty Law and Practice (2013), s. 217.

164 Villiger, Commentary on the 1969 Vienna Convention on the Law of Treaties (2009), s. 446-447 og Dörr og Schmalenbach, Vienna Convention on the Law of Treaties (2012), s. 571-572 og 577.

165 Aust, Modern Treaty Law and Practice (2013), s. 219.

${ }^{166}$ For en detaljert diskusjon, inkludert eksempler, se Dörr og Schmalenbach, Vienna Convention on the Law of Treaties (2012), s. 578-580.

167 Villiger, Commentary on the 1969 Vienna Convention on the Law of Treaties (2009), s. 445. Dette gir også mulighet for å ta hensyn til noen staters status, for eksempel som deres status som importland eller eksportland.

168 Dörr og Schmalenbach, Vienna Convention on the Law of Treaties (2012), s. 578.

${ }^{169}$ Dörr og Schmalenbach, Vienna Convention on the Law of Treaties (2012), s. 580.
} 
dette er materiale som kan belyse eller avklare materielle spørsmål, ${ }^{170}$ og ikke til alminnelige fortolkningsprinsipper eller fortolkningsteknikker som ikke ble inkludert i Wien-konvensjonen. ${ }^{171}$ Et eksempel kan være materiale som ikke direkte stammer fra forhandlingene, men som likevel har spilt en rolle fordi det utvilsomt er knyttet til traktatens innhold og fordi forhandlingspartene henviste til det under utarbeidelsesprosessen. Det kan være dokumenter fra uavhengige institusjoner eller eksperter, ${ }^{172}$ og forarbeider til traktater som er identiske med, eller i stor grad ligner på, traktaten som tolkes. ${ }^{173}$ Et annet eksempel er dokumenter fra mellomstatlige organisasjoner som jobber med saker som dekkes av traktaten, og som er tett knyttet til bestemmelsen som tolkes. ${ }^{174}$ Hvilken vekt disse supplerende tolkningsmomentene ilegges beror på de samme omstendighetene som avgjør vekten til slutninger fra forarbeidene og forhistorien, som er kommentert over.

I de aller fleste tilfeller brukes supplerende tolkningsmomenter for å bekrefte («confirm») et resultat man har kommet frem til etter en tolkning i tråd med artikkel $31 \mathrm{i}$ Wien-konvensjonen. ${ }^{175}$ Som nevnt, kan henvisningen til forarbeidene, i noen svært sjeldne ${ }^{176}$ tilfeller, avgjore («determine») resultatet av tolkningen. Dette vil være når «the interpretation according to Article 31: (a) leaves the meaning ambiguous or obscure; or (b) leads to a result which is manifestly absurd or unreasonable». Fordi det til en viss grad er subjektivt hvorvidt et resultat er «ambiguous or obscure», overlater kravene etter bokstav a) en betydelig skjønnsmargin til traktatstolkeren. Den som tolker traktaten må likevel i det minste begrunne hvorfor et tolkningsresultat er «ambiguous or obscure» etter anvendelse av artikkel $31 .{ }^{177}$ For at artikkel 32 bokstav b) skal komme til anvendelse må tolkningsresultatet etter artikkel 31 ikke bare være «absurd», men «manifestly absurd or unreasonable». Dette er en høy terskel. Et eksempel på en «manifestly absurd» tolkning av en bestemmelse, kan være et tolkningsresultat som direkte motsier en annen bestemmelse i traktaten. ${ }^{178}$

\section{Traktater på flere språk (Wien-konvensjonen artikkel 33)}

Jeg kommer nå til spørsmålet om flerspråklige traktater. Traktater inngås ofte på flere språk. For eksempel slås det fast i FN-pakten fra 1945 at dens offisielle (autentiske) språkversjoner er engelsk, fransk, kinesisk, russisk og spansk. ${ }^{179}$ De offisielle språkversjoner til delelinjeavtalen mellom Norge og Russland fra 2010 er norsk og russisk, ${ }^{180}$ mens Svalbardtraktaten fra 1920 sine autentiske språk

\footnotetext{
${ }^{170}$ Dörr og Schmalenbach, Vienna Convention on the Law of Treaties (2012), s. 580, motsatt Villiger, Commentary on the 1969 Vienna Convention on the Law of Treaties (2009), s. 445.

${ }^{171}$ For eksempel tolkningsteknikker som per analogiam, e contrario, eiusdem generis, lex posterior derogat legi priori, lex specialis derogat legi speciali, in dubio mitis, contra proferentem, osv. Disse er som regel tatt hensyn til etter artikkel 31 tredje avsnitt bokstav c) som vi har analysert ovenfor, eller som sedvanerett som anvendes sammen med Wien-reglene.

172 Dörr og Schmalenbach, Vienna Convention on the Law of Treaties (2012), s. 581

173 Villiger, Commentary on the 1969 Vienna Convention on the Law of Treaties (2009), s. 445.

${ }^{174}$ Dörr og Schmalenbach, Vienna Convention on the Law of Treaties (2012), s. 581, også med eksempler.

${ }^{175}$ En mer detaljert tolkning av ordet «confirm» som kan gis her, finnes i Dörr og Schmalenbach, Vienna Convention on the Law of Treaties (2012), s. 582-583.

${ }^{176}$ Dörr og Schmalenbach, Vienna Convention on the Law of Treaties (2012), s. 584.

177 Dörr og Schmalenbach, Vienna Convention on the Law of Treaties (2012), s. 584.

${ }^{178}$ Dörr og Schmalenbach, Vienna Convention on the Law of Treaties (2012), s. 585.

179 Artikkel 111 i FN-pakten.

180 Artikkel 8 i Overenskomst mellom Kongeriket Norge og Den Russiske Føderasjon om maritim avgrensning og samarbeid i Barentshavet og Polhavet, vedtatt 15. september 2010, trådt i kraft 7. juli 2011, https://www.regjeringen.no/globalassets/upload/ud/vedlegg/folkerett/avtale norsk.pdf
} 
er engelsk og fransk. ${ }^{181}$ Ofte er det ikke mulig å oversette alle ord og uttrykk som brukes i en traktat presist. Derfor er det uunngåelig at det oppstår nyanseforskjeller mellom språkversjonene, slik vi også så i eksempelet over under punkt 3.2. ${ }^{182}$

Ved tolkning av flerspråklige traktater er det viktig å holde seg til de autentiske tekstene, og ikke uoffisielle oversettelser, som for eksempel norsk. ${ }^{183}$ Dette er også grunnen til at jeg i denne artikkelen har brukt den offisielle engelske teksten fra Wien-konvensjonen og andre traktater, og ikke en uoffisiell norsk oversettelse.

Wien-konvensjonens artikkel 33 første avsnitt fastsetter at de offisielle tekstene er likeverdige, med mindre noe annet fremgår av traktaten selv. ${ }^{184}$ For eksempel finnes traktater med flere offisielle språk, men som samtidig bestemmer at ved uoverensstemmelse mellom de offisielle tekstene skal ett språk gis forrang: Som oftest vil det være språket som er mest brukt under traktatsforhandlingene. Jeg vil trekke frem to eksempler: ${ }^{185}$

- «Done at Kuwait this twenty-fourth day of April, in the year one thousand nine hundred and seventy-eight in the Arabic, English and Persian languages, the three texts being equally authentic. In case of a dispute as to the interpretation or application of the Convention or its protocols, the English text shall be dispositively authorative.»1186 (Min utheving.)

- «Done at Brussels, this 27th day of June 1997, in the German, English, Bulgarian, Croatian, Danish, Spanish, French, Greek, Hungarian, Italian, Dutch, Norwegian, Portuguese, Romanian, Slovak, Slovenian, Swedish, Czech and Turkish languages, in a single original, which shall remain deposited in the archives of the Government of the Kingdom of Belgium which shall transmit certified copies to the Governments of the other signatory States. In the case of any inconsistency, the text in the French language shall prevail.»1 ${ }^{187}$ (Min utheving.)

Artikkel 33 tredje og fjerde avsnitt forklarer hva som skal gjøres ved uoverensstemmelser mellom de autentiske tekstene. Artikkel 33 tredje avsnitt fastsetter:

«The terms of the treaty are presumed to have the same meaning in each authentic text.»

I sin praktiske anvendelse innebærer bestemmelsen at de som tolker traktaten må sammenligne tekstene i alle offisielle språk, og finne en felles mening. ${ }^{188}$ Et eksempel er ICJs uttalelser i saken Kasikili/Sedudu Island (Botswana mot Namibia). ${ }^{189}$ I denne saken sammenlignet ICJ de engelske og tyske begrepene «centre of the [main] channel» og «Thalweg des Hauptlaufes» som ble brukt $\mathrm{i}$ Anglo-German Treaty fra 1890, og fastsatte at de har samme mening:

\footnotetext{
${ }^{181}$ Artikkel 10 i Traktat mellem Norge, Amerikas Forente Stater, Danmark, Frankrike, Italia, Japan, Nederlandene, Storbritannia og Irland og de britiske oversjøiske besiddelser og Sverige angående Spitsbergen (Svalbardtraktaten), vedtatt 9. februar 1920, trådt i kraft 14. august 1925.

182 Villiger, Commentary on the 1969 Vienna Convention on the Law of Treaties (2009), s. 456 og Dörr og Schmalenbach, Vienna Convention on the Law of Treaties (2012), s. 587.

183 Ruud og Ulfstein, Innforing i folkerett (2011), s. 91.

${ }^{184}$ I artikkel 33 første ledd i Wien-konvensjonen står det: «1. When a treaty has been authenticated in two or more languages, the text is equally authoritative in each language, unless the treaty provides or the parties agree that, in case of divergence, a particular text shall prevail».

185 Disse eksemplene er tatt fra Aust, Modern Treaty Law and Practice (2013), s. 223-224. Flere eksempler finnes i Dörr og Schmalenbach, Vienna Convention on the Law of Treaties (2012), s. 595.

186 Art.XXX b), Kuwait Regional Convention for Cooperation on the Protection of the Marine Environment from Pollution, 1978.

187 Art.V, Protocol consolidating the Eurocontrol International Convention relating to Co-operation for the Safety of Air Navigation of 13 December 1960, as variously amended, 27 June 1997.

188 Dörr og Schmalenbach, Vienna Convention on the Law of Treaties (2012), s. 593-594 og 597-599.

189 ICJ, Case concerning Kasikili/Sedudu Island (Botswana mot Namibia).
} 
«25. The Court further notes that at the time of the conclusion of the 1890 Treaty, it may be that the terms 'centre of the [main] channel and 'Thalweg des Hauptlaufes' were used interchangeably. In this respect, it is of interest to note that, some three years before the conclusion of the 1890 Treaty, the Institut de droit international stated the following in Article 3, paragraph 2, of the 'Draft concerning the international regulation of fluvial navigation', adopted at Heidelberg on 9 September 1887: 'The boundary of States separated by a river is indicated by the thalweg, that is to say, the median line of the channel' (Annuaire de l'Institut de droit international, 1887-1888, p. 182), the term 'channel' being understood to refer to the passage open to navigation in the bed of the river, as is clear from the title of the draft. Indeed, the parties to the 1890 Treaty themselves used the terms 'centre of the channel and 'thalweg' as synonyms, one being understood as the translation of the other.» ${ }^{190}$ (Min utheving.)

Artikkel 33 fjerde avsnitt kommer inn når konflikter mellom de autentiske språkversjonene ikke kan løses gjennom sammenligninger, det vil si når man ikke finner en felles mening i tekstene. ${ }^{191} \mathrm{I}$ dette tilfellet skal en velge

«... the meaning which best reconciles the [authentic] texts, having regard to the object and purpose of the treaty». ${ }^{192}$ (Min utheving.)

I praksis anvendes denne bestemmelsen svært sjelden, men vi har en ICJ-sak hvor den hadde stor betydning: dette er LaGrand-saken (Tyskland mot USA) fra 2001. ${ }^{193}$ Her undersøkte domstolen den bindende karakteren av midlertidige tiltak (provisional measures) som domstolen kan vedta etter ICJ-statuttene artikkel 41, og om brudd på midlertidige tiltak fastsatt av ICJ er et folkerettsbrudd. ${ }^{194}$ Domstolen kom frem til at det var en ulikhet mellom de offisielle franske og engelske tekstene i ICJ-statuttene, og anvendte derfor Wien-konvensjonen artikkel 33 fjerde avsnitt. Dermed konsentrerte domstolen seg om formålet med statuttene. ICJ mente at formålet med ICJ-statuttene er å «enable the Court to fulfil ... [its] basic function of judicial settlement of international disputes by binding decisions ...». ${ }^{195}$ Med henvisning til dette formålet konkluderte ICJ at midlertidige tiltak må være folkerettslig bindende for statene:

«101. Finding itself faced with two texts which are not in total harmony, the Court will first of all note that according to Article 92 of the Charter, the Statute 'forms an integral part of the present Charter'. Under Article 111 of the Charter, the French and English texts of the latter are 'equally authentic'. The same is equally true of the Statute. In cases of divergence between the equally authentic versions of the Statute, neither it nor the Charter indicates how to proceed. In the absence of agreement between the parties in this respect, it is appropriate to refer to paragraph 4 of Article 33 of the Vienna Convention on the Law of Treaties, which in the view of the Court again reflects customary international law. ... This provision reads 'when a comparison of the authentic texts discloses a difference of meaning which the application of Articles 31 and 32 does not remove the meaning which best reconciles the texts, having regard to the object and purpose of the treaty, shall be adopted'.

${ }^{190}$ ICJ, Case concerning Kasikili/Sedudu Island (Botswana mot Namibia), avsnitt 25.

191 Dörr og Schmalenbach, Vienna Convention on the Law of Treaties (2012), s. 599-601.

192 Wien-konvensjonen artikkel 33 fjerde avsnitt.

193 ICJ, LaGrand. Dörr og Schmalenbach, Vienna Convention on the Law of Treaties (2012), analyserer dette eksempelet på s. 600 .

${ }^{194}$ ICJ-Statutt artikkel 41: «(1) The Court shall have the power to indicate, if it considers that circumstances so require, any provisional measures which ought to be taken to preserve the respective rights of either party. (2) Pending the final decision, notice of the measures suggested shall forthwith be given to the parties and to the Security Council.»Og den franske teksten: «(1) La Cour a le pouvoir d'indiquer, si elle estime que les circonstances l'exigent, quelles mesures conservatoires du droit de chacun doivent être prises à titre provisoire. (2) En attendant l'arrêt définitif, l'indication de ces mesures est immédiatement notifiée aux parties et au Conseil de sécurité.» (Mine uthevinger).

195 ICJ, LaGrand, avsnitt 102. 
102. The object and purpose of the Statute is to enable the Court to fulfil the functions provided for therein, and, in particular, the basic function of judicial settlement of international disputes by binding decisions in accordance with Article 59 of the Statute. The context in which Article 41 has to be seen within the Statute is to prevent the Court from being hampered in the exercise of its functions because the respective rights of the parties to a dispute before the Court are not preserved. It follows from the object and purpose of the Statute, as well as from the terms of Article 41 when read in their context, that the power to indicate provisional measures entails that such measures should be binding, inasmuch as the power in question is based on the necessity, when the circumstances call for it, to safeguard, and to avoid prejudice to, the rights of the parties as determined by the final judgment of the Court. The contention that provisional measures indicated under Article 41 might not be binding would be contrary to the object and purpose of that Article.» (Mine uthevninger.)

Wien-konvensjonen artikkel 33 fjerde avsnitt inneholder til slutt et tilsvarende unntak som i artikkel 33 første avsnitt: nemlig at en traktat kan bestemme at det ved divergens mellom de offisielle tekster, er det et språk som skal gis forrang. ${ }^{196}$

7. Avsluttende refleksjoner

I artikkelen har jeg gitt en kort oversikt over Wien-konvensjonens regler om traktatstolkning. Analysen viser at det å tolke traktater er en kompleks oppgave som krever bevissthet og presisjon fra den som tolker. A tolke vage traktatsbestemmelser i tråd med Wien-konvensjonens krav kan noen ganger være vanskelig. Like fullt er det juristenes oppgave å gjøre nettopp dette på en overbevisende måte, i samsvar med de lagdelte kravene som konvensjonen oppstiller. Følges Wienkonvesjonens regler lojalt får vi en objektiv ${ }^{197}$ tolkning, som igjen vil føre til at traktatspartenes intensjoner realiseres. Dette er sentralt for å skape en enhetlig folkerett som forstås, deles og praktiseres av jurister verden rundt. Dette følger også av prinsippet om god tro, og erkjennelsen av de konkrete konsekvenser traktatstolkning kan ha for enkeltmennesket og verdenssamfunnet, som fremhevet $\mathrm{i}$ innledningen. Mange folkerettslige traktater har nettopp som overordnet mål å oppnå beskyttelse av enkeltmennesker, (verdens)samfunnet og miljøet, ofte gjennom en balansering av motstridende interesser.

\footnotetext{
${ }^{196}$ I Wien-konvensjonen, artikkel 33 fjerde ledd står det: «4. Except where a particular text prevails in accordance with paragraph 1 , when a comparison of the authentic texts discloses a difference of meaning which the application of articles 31 and 32 does not remove, the meaning which best reconciles the texts, having regard to the object and purpose of the treaty, shall be adopted.»

${ }_{197}$ Mange av Wien-konvensjonens regler gir selvfølgelig en skjønnsmargin til de som tolker traktater, og derfor er det vanskelig å snakke om et helt objektivt tolkningsresultat. Men dette er uunngåelig i en situasjon hvor det må være mulig å anvende Wien-reglene effektivt i stadig skiftende omstendigheter, og prinsippet om god tro er et virkemiddel mot misbruket av skjønnsmarginen.
} 